\title{
Supplemental Tables and Figures
}

\section{A triazolopyrimidine-based dihydroorotate dehydrogenase inhibitor (DSM421) with improved drug-like}

\section{properties for treatment and prevention of malaria}

Margaret A. Phillips ${ }^{1 *}$, Karen L. White ${ }^{2}$, Sreekanth Kokkonda $^{3}$, Xiaoyi Deng ${ }^{1}$, John White ${ }^{3}$, Farah El Mazouni ${ }^{1}$, Kennan Marsh ${ }^{4}$, Diana R. Tomchick ${ }^{5}$, Krishne Manjalanagara ${ }^{6}$, Kakali Rani Rudra ${ }^{6}$, Grennady Wirjanata ${ }^{7}$, Rintis Noviyanti ${ }^{8}$, Ric N Price ${ }^{7,9}$, Jutta Marfurt ${ }^{7}$, David M. Shackleford ${ }^{2}$, Francis C.K. Chiu ${ }^{2}$, Michael Campbell ${ }^{2}$, Maria Belen Jimenez-Diaz ${ }^{1{ }^{\wedge}}$, Santiago Ferrer Bazaga ${ }^{10}$, Iñigo Angulo-Barturen ${ }^{10^{\wedge}}$, Maria Santos Martinez ${ }^{10}$, Maria Lafuente-Monasterio $^{10}$, Werner Kaminsky ${ }^{3}$, Kigbafori Silue ${ }^{11}$, Anne-Marie Zeeman ${ }^{12}$, Clemens Kocken ${ }^{12,}$ Didier Leroy $^{13}$, Benjamin Blasco ${ }^{13}$, Emilie Rossignol ${ }^{13}$, Thomas Rueckle ${ }^{13}$, Dave Matthews ${ }^{13}$, Jeremy N. Burrows ${ }^{13}$, David Waterson $^{13}$, Michael J. Palmer ${ }^{13}$, Pradipsinh K. Rathod ${ }^{3}$ and Susan A. Charman ${ }^{2 *}$

${ }^{1}$ Departments of Pharmacology and ${ }^{5}$ Biophysics, University of Texas Southwestern Medical Center at Dallas, 6001 Forest Park Blvd, Dallas, Texas 75390-9041; ${ }^{2}$ Centre for Drug Candidate Optimisation, Monash Institute of Pharmaceutical Sciences, Monash University, Parkville, VIC 3052, Australia, ${ }^{3}$ Departments of Chemistry and Global Health, University of Washington, Seattle, WA 98195; ${ }^{4}$ Abbvie, 1 North Waukegan Road, North Chicago, Il 60064-6104; ${ }^{6}$ Syngene International Ltd, Bangalore, India, 560 099; ${ }^{7}$ Global and Tropical Health Division, Menzies School of Health Research, Charles Darwin University, PO Box 41096, Casuarina, NT 0811, Darwin, Australia; ${ }^{8}$ Eijkman Institute for Molecular Biology, J1. Diponegoro 69, 10430 Jakarta, Indonesia; ${ }^{9}$ Centre for Tropical Medicine and Global Health, Nuffield Department of Clinical Medicine, University of Oxford, OX3 7LJ, UK; ${ }^{10} \mathrm{GSK}$, Tres Cantos Medicines Development Campus, Severo Ochoa, Madrid, 28760 Spain; ${ }^{11}$ Centre Suisse de Recherches Scientifiques en Côte d'Ivoire (CSRS), Km17, Route de Dabou, Adipodoumé, 01 BP 1303 Abidjan, Côte d'Ivoire; ${ }^{12}$ Biomedical Primate Research Centre, Netherlands ${ }^{13}$ Medicines for Malaria Venture, 1215 Geneva, Switzerland. 


\section{Table of Contents.}

\section{Supplemental Methods}

Scheme S1. Overall synthetic route for compounds described in Table 1

Scheme S2. Synthesis of DSM565

Table S1. X-ray diffraction data and refinement statistics for PfDHODH bound to DSM421

Table S2. DSM421 In vitro antimalarial activity

Table S3. In vitro parasite reduction ratio (kill rate)

Table S4A. Activity of DSM421 against $P$. falciparum and $P$. vivax field isolates

Table S4B. Activity of DSM265 against $P$. falciparum and $P$. vivax field isolates

Table 5A. Comparison of in vivo P. falciparum efficacy with standard antimalarials

Table 5B. DSM421 SCID mouse blood PK data

Table S6. Comparison of physicochemical properties between DSM421 and DSM265

Table S7. Permeability of DSM421 across confluent and differentiated Caco- 2 cell monolayers

Table S8. In vitro metabolism of DSM421 in hepatic microsomes and cryopreserved hepatocytes

Table S9. Plasma and media protein binding and blood to plasma partitioning ratios for DSM421

Table S10. Specific CYP-mediated metabolic pathways, conditions and reference inhibitors for reversible CYP inhibition studies

Table S11. Reversible inhibition of CYP isoforms by DSM421

Table S12. Specific CYP-mediated metabolic pathways, conditions and reference inhibitors using for timedependent CYP inhibition studies

Table S13. Time-dependent inhibition data for DSM421 against 5 major CYP isoforms

Table S14. DSM421 dosing conditions for preclinical pharmacokinetic studies

Table S15. Pharmacokinetic parameters for DSM421 following IV and oral administration to non-fasted mice

Table S16. Pharmacokinetic parameters for DSM421 following IV and oral administration to fasted rats

Table S17. Pharmacokinetic parameters for DSM421 following IV and oral administration to fasted dogs

Table S18. DSM421 Summary of safety pharmacology data

Table S19. Small molecule crystallographic data for DSM421

Fig. S1. Density maps for the DSM421:PfDHODH binding-site

Fig. S2. Stereo view of the superimposed DSM421 and DSM265 binding sites within the $4 \AA$ shell

Fig. S3 ORTEP diagram of the DSM421 structure 


\section{Supplemental Methods}

\section{Ex vivo schizont maturation drug susceptibility assay against $P$. vivax and $P$. falciparum field isolates}

Compounds were prepared as $1 \mathrm{mg} / \mathrm{mL}$ stock solutions in water or DMSO according to the supplier's instructions. Stock solutions of both DSM421 and DSM265 were prepared in DMSO. With the exception of DSM265, drug plates were pre-dosed by diluting the compounds in 50\% methanol followed by lyophilization and storage at $4{ }^{\circ} \mathrm{C}$. A 2 -fold dilution series was prepared for each compound, with the top concentration as follows: chloroquine $(3.0 \mu \mathrm{M})$, amodiaquine $(0.16 \mu \mathrm{M})$, piperaquine $(1.0 \mu \mathrm{M})$, mefloquine $(0.34 \mu \mathrm{M})$, artesunate $(0.049$ $\mu \mathrm{M})$ and DSM421 $(2.1 \mu \mathrm{M})$. For DSM265, solubility issues made it difficult to resuspend drug from lyophilized plates and therefore fresh drug was added to plates in the field. Stock solutions of $1 \mathrm{mg} / \mathrm{ml}$ in DMSO were diluted 1 to 100 in media, and the resulting solution was used to make 11 two-fold serial dilutions covering the concentration range $(0.029-15 \mu \mathrm{M})$, resulting in a final DMSO concentration of $0.5 \%$. Stock solutions were protected from light.

Drug was incubated with parasites in a candle jar at $37.0^{\circ} \mathrm{C}$ for $35-56 \mathrm{~h}$ until $>40 \%$ of ring stage parasites reached the mature schizont stage in the drug-free control wells. Thick blood films were stained with $5 \%$ Giemsa solution for $0.5 \mathrm{~h}$ and scored by microscopy. The percentage of schizonts out of a total of 200 asexual stage parasites was determined and normalized to the no drug control well. Dose-response data were analyzed using nonlinear regression analysis (WinNonlin 4.1, Pharsight Corporation) and the $\mathrm{EC}_{50}$ derived using an inhibitory sigmoidal $\mathrm{E}_{\max }$ model. Data were only used if $\mathrm{E}_{\max }$ and $\mathrm{E}_{0}$ were within $15 \%$ of 100 and $1 \%$, respectively.

\section{Permeability in Caco-2 cells}

Caco-2 cells (passages 32 or 36 ) were seeded onto $0.3 \mathrm{~cm}^{2}$ polycarbonate filter transwells at a density of 60,000 cells per well. The transport experiment was conducted using confluent cell monolayers on day 23 postseeding. The integrity of the monolayers was confirmed by measuring the transepithelial electrical resistance (TEER) and only monolayers with TEER values of $>300 \Omega . \mathrm{cm} 2$ were utilized. The permeability of control compounds including ${ }^{14} \mathrm{C}$-mannitol (low permeability marker), ${ }^{3} \mathrm{H}$-propranolol (high permeability marker) and ${ }^{3} \mathrm{H}$ digoxin (P-gp efflux marker) was also assessed in the same experiment to ensure consistency with literature and historical values. Permeability experiments were performed using Hanks balanced salt solution containing $20 \mathrm{mM}$ HEPES buffer (pH 7.4) in both the apical and basolateral chambers. Donor solutions were prepared by spiking a DMSO solution of DSM421 into transport buffer (resulting in a final DMSO concentration of $0.1 \% \mathrm{v} / \mathrm{v}$ ) at a nominal concentration of $20 \mu \mathrm{M}$ and equilibrating at $37^{\circ} \mathrm{C}$ and then centrifuging to remove any undissolved material. Samples from the donor chamber were taken at the start and end of the experiment to confirm mass balance. Compound flux was determined over a period of 90 minutes, with samples taken from the acceptor chamber at five to seven time points over the course of the incubation. At each sample time, the volume of acceptor solution removed was replaced with blank transport buffer. Acceptor concentrations were assayed for DSM421 as described below for plasma samples, and concentrations were corrected for the dilution that occurred with buffer replacement. Apparent permeability $\left(\mathrm{P}_{\mathrm{app}}\right)$ values were calculated using the linear portion of the flux profiles.

\section{In vitro metabolism}

Metabolism samples were analyzed using a Waters Xevo G2 QTOF coupled to a Waters Acquity UPLC (both Waters Corporation, Milford, MA). The column was an Ascentis Express RP Amide column (50 x $2.1 \mathrm{~mm}$, $2.7 \mu \mathrm{m}$ ) and the mobile phase solvents were water and acetonitrile (both containing $0.05 \% \mathrm{v} / \mathrm{v}$ formic acid) mixed using a $4 \mathrm{~min}$ gradient at a flow rate of $0.4 \mathrm{~mL} / \mathrm{min}$. Compounds were injected at a volume of $5 \mu \mathrm{L}$ and the column was re-equilibrated at the starting conditions for $2 \mathrm{~min}$. Mass spectrometry was conducted using positive electrospray ionization under MSE acquisition mode with cone and CID voltages of 30 and 20-30 V, respectively. Metabolite identification was conducted using accurate mass and high collision energy data. 
The in vitro intrinsic clearance $\left(\mu \mathrm{L} / \mathrm{min} / \mathrm{mg}\right.$ protein or $\mu \mathrm{L} / \mathrm{min} / 10^{6}$ cells) was determined using the first order substrate depletion data and scaled to an in vivo intrinsic clearance $(\mathrm{mL} / \mathrm{min} / \mathrm{kg})$ using physiologically-based scaling factors ${ }^{l}$. The well-stirred model of hepatic extraction was used to calculate a predicted blood and plasma clearance taking into account binding to microsomes (measured) or hepatocytes (calculated as described ${ }^{l}$ ) and the fraction unbound in blood (calculated by dividing the fraction unbound in plasma by the blood to plasma ratio).

\section{CYP Inhibition}

DSM421 was incubated $\left(37^{\circ} \mathrm{C}\right)$ with human liver microsomes and substrates known to be metabolized by specific CYP isoforms. A list of specific CYP-mediated metabolic pathways, probe substrates, conditions and positive control inhibitors is shown in Table S10. Reactions were initiated and quenched as described for the microsomal stability studies ${ }^{2}$. The concentration of DSM421 that led to $50 \%$ inhibition of metabolite formation was expressed as an $\mathrm{IC}_{50}$. Positive control inhibitors were included in the assay and all showed $\mathrm{IC}_{50}$ values consistent with the literature and historical values. Concentrations were determined by UPLC-MS (Waters Quattro Ultima Premier or Waters Xevo triple-quadrupole) relative to calibration standards prepared in quenched microsomal matrix.

Time-dependent CYP inhibition was assessed using human liver microsomes and isoform specific metabolic substrates by preincubating DSM421 (at 10-fold the final concentration) with microsomes in the absence or presence of NADPH at $37^{\circ} \mathrm{C}$ for $30 \mathrm{~min}$. Reaction mixtures were then diluted 10-fold with NADPH regenerating buffer containing the probe substrates. A list of specific CYP-mediated metabolic pathways, probe substrates, conditions and positive control inhibitors is shown in Table S12. Following the final incubation, $\mathrm{IC}_{50}$ values were determined as described above for each preincubation condition (i.e. with or without NADPH). Samples were quenched and assayed as described for the microsomal stability studies ${ }^{2}$. A shift to a lower $\mathrm{IC}_{50}$ (more than 1.5-fold) for samples preincubated with NADPH compared to preincubation in the absence of NADPH was considered evidence for mechanism-based inhibition.

\section{LC/MS analysis of DSM421 in rat and mouse plasma}

Monash single dose PK studies. Plasma samples and standards were prepared by precipitation with acetonitrile (3:1 volume ratio), followed by centrifugation and analysis of the supernatant. Samples $(3 \mu \mathrm{L})$ were injected onto a Supelco Ascentis Express RP-Amide column $(2.7 \mu \mathrm{m}$ particle size, 50 x $2.1 \mathrm{~mm}$ i.d.) with a Phenomenex Polar Security Guard column at a column temperature of $40^{\circ} \mathrm{C}$. The mobile phase solvents consisted of water and methanol, each containing $0.05 \%$ formic acid, mixed using a linear gradient program and delivered at a flow rate of $0.4 \mathrm{~mL} / \mathrm{min}$. The chromatographic system comprised a Waters Acquity UPLC and a Waters/Micromass Quattro Premier or a Waters Xevo TQ triple quadrupole mass spectrometer. Analytes were ionized using positive electrospray ionization using a cone voltage of $35 \mathrm{~V}$ and a collision induced dissociation voltage of $25 \mathrm{~V}$ and detection by multiple reaction monitoring (MRM) using a transition (m/z) of $359.10>$ 339.07. Sample concentrations were determined by comparison to calibration standards prepared in blank plasma from each species. The analytical lower limit of quantitation (LLQ) value for DSM421 in plasma was typically 1 $\mathrm{ng} / \mathrm{mL}$ and accuracy $(+/-12 \%)$, precision $(<10 \%$ relative standard deviation) and recovery $(>90 \%)$ were within acceptable limits.

GSK PK analysis during SCID mouse efficacy studies. Peripheral whole blood samples (25 $\mu \mathrm{l})$ were collected at $0.25,0.5,1,2,4,6,8$ and $23 \mathrm{~h}$ after the first dose. Samples were mixed with an equal volume of saponine solution $\left(0.1 \%\right.$ in water) and immediately frozen on dry ice and stored at $-80^{\circ} \mathrm{C}$ prior to analysis. Blood samples were processed by mixing diluted blood $(10 \mu l)$ with acetonitrile/methanol $(80: 20 \mathrm{v}: \mathrm{v})(120 \mu \mathrm{l})$ followed by centrifugation. The supernatant was then analyzed by UPLC/MSMS using a Waters UPLC coupled to a Sciex API4000 mass spectrometer. The 
lower limit of quantification (LLOQ) was $5 \mathrm{ng} / \mathrm{mL}$ for DSM421. Blood concentration versus time profiles were analyzed by non-compartmental methods using Phoenix software (ver. 6.3, Pharsight).

\section{LC/MS analysis of DSM421 in dog plasma}

Dog plasma samples and standards were assayed for DSM421 following protein precipitation with acetonitrile (5:1 volume ratio). Samples were centrifuged and the supernatant transferred to a fresh plate containing an aqueous solution of $0.1 \%$ formic acid and $25 \mu \mathrm{L}$ was injected onto the column. Analysis was conducted using a Supelco Ascentis Express column $(30 \times 3 \mathrm{~mm}, 2.7 \mu \mathrm{m})$ with an acetonitrile/0.1\% formic acid mobile phase gradient which initiated with $30 \%$ acetonitrile, increasing to $50 \%$ acetonitrile at 0.25 minutes, returning to $30 \%$ acetonitrile at 0.95 minutes and maintaining $30 \%$ acetonitrile through 1.2 minutes; the flow rate was maintained a $0.8 \mathrm{~mL} / \mathrm{min}$. Detection was via a Sciex API5000 ${ }^{\mathrm{TM}}$ Biomolecular Mass Analyzer with a turboionspray interface. Analytes were ionized in the positive ion mode with a source temperature of approximately $550^{\circ} \mathrm{C}$. Detection was in the multiple reaction monitoring (MRM) mode at $m / z 359.176 \rightarrow 339.03$ for DSM421. Concentrations were determined by comparison to a calibration curve prepared in blank dog plasma. The method provided mean percent accuracy ranging from 93.0-103.7\% across the calibration range, reproducibility (\%CV) ranging from 1.0-16.0\%, and a lower limit of quantitation of $\sim 3 \mathrm{ng} / \mathrm{mL}$.

\section{Human half-life and dose predictions}

Human PK parameters were estimated using a physiologically based pharmacokinetic (PBPK) approach. Clearance was predicted by in vitro/in vivo extrapolation (IVIVE) of $\mathrm{CL}_{\mathrm{int}}$ data following incubation with human liver microsomes (Table S9), using the well-stirred model of hepatic extraction and physiologically-based scaling factors, taking into account binding to both human liver microsomes and human plasma (Table S9) ${ }^{l}$. Human unbound clearance was also estimated using allometric scaling of unbound clearance values measured after IV administration to mice, rats and dogs by plotting the log unbound clearance versus the log body weight.

Assuming only hepatic elimination, the estimated unbound $\mathrm{CL}_{\text {int }}$, together with measured values for $\log$ $\mathrm{D}_{7.4}$, solubility in physiologically relevant media, permeability across Caco-2 cell monolayers, human plasma protein binding and blood to plasma partitioning, were input into a PBPK software package (GastroPlus ${ }^{\mathrm{TM}}$, version 9) and tissue Kp values were estimated using the Rodgers and Rowland method ${ }^{3,4}$ for perfusion limited tissue distribution. Plasma concentration versus time profiles following oral administration of an immediate release tablet were simulated at various doses using GastroPlus incorporating the ACAT model and human fastedstate conditions to estimate the rate and extent of absorption.

The target minimum plasma concentration needed to achieve a near maximal rate of kill (minimum parasiticidal concentration or MPC) was estimated empirically using the in vitro PRR data and in vivo efficacy data from SCID mice. The unbound $\mathrm{EC}_{50}$ from the in vitro PRR assay (Table 3) was multiplied by 3 to give an estimated unbound MPC based on data for DSM265 . This value was then divided by the human plasma free fraction (Table S9) to obtain the target total plasma concentration.

For the in vivo efficacy data in SCID mice, the minimum blood concentration required to produce the maximum rate of kill was taken from visual inspection of the data shown in Figure 5B. The unbound plasma concentration in SCID mice was then derived using an estimated SCID mouse fraction unbound and blood to plasma ratio and calculated as follows.

The fraction unbound in SCID mouse plasma was estimated assuming that the mice had similar proportions of human and mouse plasma at the time of drug dosing. Assuming a single family of binding sites in plasma from each species, the bound concentration $\left(\mathrm{C}_{\text {bound }}\right)$ can be expressed as: 


$$
\mathrm{C}_{\text {bound }}=\left(\mathrm{B}_{\max } * \mathrm{C}_{\text {free }}\right) /\left(\mathrm{K}_{\mathrm{d}}+\mathrm{C}_{\text {free }}\right)
$$

where $\mathrm{B}_{\max }$ is a hybrid constant incorporating the number of binding sites per mole of protein and the molar protein concentration, $\mathrm{Kd}$ is the dissociation constant and $\mathrm{C}_{\text {free }}$ is the unbound concentration ${ }^{6}$. Assuming that the unbound concentration in plasma from each species is much less than the respective $\mathrm{K}_{\mathrm{d}}$ value, this equation simplifies to:

$$
\mathrm{C}_{\mathrm{bound}}=\left(\mathrm{B}_{\max } * \mathrm{C}_{\text {free }}\right) / \mathrm{K}_{\mathrm{d}}
$$

Knowing that the total concentration is equal to the sum of the bound and free concentrations, the following expression for $\mathrm{B}_{\max }$ in plasma for each species can then be derived:

$$
\mathrm{B}_{\max }=\left(\mathrm{K}_{\mathrm{d}} *\left(1-\mathrm{F}_{\mathrm{u}}\right)\right) / \mathrm{F}_{\mathrm{u}}
$$

In SCID mice where plasma is a mixture of mouse and human plasma, $\mathrm{B}_{\max }$ for each species plasma will be related to the fraction of each species plasma present:

$$
\begin{aligned}
& \mathrm{B}_{\max }{ }^{\text {human }}=\left(\mathrm{H} * \mathrm{~K}_{\mathrm{d}}^{\text {human }} *\left(1-\mathrm{F}_{\mathrm{u}}^{\text {human }}\right)\right) /\left(\mathrm{F}_{\mathrm{u}}{ }^{\text {human }}\right) \\
& \text { and } \\
& \mathrm{B}_{\max }^{\text {mouse }}=\left((1-\mathrm{H}) * \mathrm{~K}_{\mathrm{d}}^{\text {mouse }} *\left(1-\mathrm{F}_{\mathrm{u}}^{\text {mouse }}\right)\right) /\left(\mathrm{F}_{\mathrm{u}}{ }^{\text {mouse }}\right)
\end{aligned}
$$

where $\mathrm{H}$ is the fraction of human plasma in SCID mice, $(1-\mathrm{H})$ is the fraction of mouse plasma, and $\mathrm{K}_{\mathrm{d}}$ (human and mouse) and $F_{u}$ (human and mouse) reflect the values for pure human and pure mouse plasma. In mixed plasma present in the SCID mice, the fraction unbound $\left(\mathrm{F}_{\mathrm{u}}{ }^{\text {SCID }}\right)$ can be expressed as a ratio of the free concentration $\left(\mathrm{C}_{\text {free }}\right.$ SCID $)$ to the total concentration where the total is the sum of the free, the concentration bound to human plasma proteins, and the concentration bound to the mouse plasma proteins:

$$
\mathrm{F}_{\mathrm{u}}^{\mathrm{SCID}}=\mathrm{C}_{\text {free }}{ }^{\mathrm{SCID}} /\left[\mathrm{C}_{\text {free }}{ }^{\mathrm{SCID}}+\left(\mathrm{C}_{\text {free }}{ }^{\mathrm{SCID}} * \mathrm{~B}_{\max }{ }^{\text {human }}\right) / \mathrm{K}_{\mathrm{d}}^{\text {human }}+\left(\mathrm{C}_{\text {free }}{ }^{\mathrm{SCID}} * \mathrm{~B}_{\text {max }}{ }^{\text {mouse }}\right) / \mathrm{K}_{\mathrm{d}}^{\text {mouse }}\right]
$$

Simplifying equation (6) and substituting in equations (4) and (5) then gives:

$$
\mathrm{F}_{\mathrm{u}}^{\mathrm{SCID}}=1 /\left[1+\mathrm{H} *\left(1-\mathrm{F}_{\mathrm{u}}^{\text {human }}\right) / \mathrm{F}_{\mathrm{u}}^{\text {human }}+(1-\mathrm{H}) *\left(1-\mathrm{F}_{\mathrm{u}}^{\text {mouse }}\right) /\left(\mathrm{F}_{\mathrm{u}}^{\text {mouse }}\right)\right]
$$

Using equation (7) the fraction unbound in SCID mouse plasma could then be calculated using the fraction unbound in each species plasma and the estimated proportion of human and mouse plasma in SCID mice.

The SCID mouse blood to plasma partitioning ratio $\left(\mathrm{K}_{\mathrm{b} / \mathrm{p}}^{\mathrm{SCID}}\right)$ was estimated using the following approach. The unbound erythrocyte to plasma partition coefficients $\left(\mathrm{K}_{\mathrm{e} / \mathrm{p} \text {,un }}\right)$ in human and mouse blood were first calculated using the measured blood to plasma ratio $\left(\mathrm{K}_{\mathrm{b} / \mathrm{p}}\right)$, the measured fraction unbound $\left(\mathrm{F}_{\mathrm{u}}\right)$ and the hematocrit $(\mathrm{Hct})$ for each species using the following equation ${ }^{7}$ :

$$
\mathrm{K}_{\mathrm{e} / \mathrm{p}, \text { un }}=\mathrm{K}_{\mathrm{b} / \mathrm{p}}-(1-\mathrm{Hct}) / \mathrm{F}_{\mathrm{u}} * \mathrm{Hct}
$$

The $\mathrm{K}_{\mathrm{e} / \mathrm{p} \text {, un }}$ SCID was then estimated as the weighted average of the values for human and mouse blood using the percentage of human erythrocytes $(\sim 70 \%)$ engrafted in the SCID mice. The blood to plasma ratio in SCID mice 
was then estimated as:

$$
\mathrm{K}_{\mathrm{b} / \mathrm{p}}^{\mathrm{SCID}}=\mathrm{K}_{\mathrm{e} / \mathrm{p}, \text { un }} \mathrm{SCID}^{\mathrm{S}} * \mathrm{~F}_{\mathrm{u}}^{\mathrm{SCID}} * \mathrm{Hct}+(1-\mathrm{Hct})
$$

where $\mathrm{F}_{\mathrm{u}}$ SCID was obtained as described above and Hct in SCID mice was based on an average hematocrit of 0.78 (Santiago Ferrer-Bazaga, personal communication).

The target blood concentration based on the data in SCID mice was corrected for the estimated SCID blood to plasma ratio and plasma protein binding to obtain an unbound target plasma concentration, and this value was then divided by the human plasma protein binding to obtain an estimate of the target total human plasma concentration.

\section{Safety Pharmacology.}

CEREP panel, hERG and other channel assays. CEREP assays (Express $\mathrm{S}$ profile) were performed by CEREP (Bois l'Evêque, France), 25\% inhibition is the cut off for significance. hERG, Ca_1.2 and NaV1.5 channel assays were performed using IonWorks patch clamp electrophysiology at Essen Labs (Hertfordshire, UK).GLP Ames study. A GLP Ames test was run on a highly purified batch of compound (99.6\% pure by HPLC at $255 \mathrm{nM}$ ). This study was run using a standard Ames test plate assay contracted to (WuXi AppTec Cp. Suzhou, China). The tester strains used in the definitive mutagenicity assay were Salmonella typhimurium tester strains TA98, TA100, TA1535, and TA1537 and Escherichia coli tester strain WP2 uvrA. The assay was conducted in the presence and absence of the S9 mix along with concurrent negative/solvent control and positive controls. The dose levels tested in the definitive mutagenicity assay were 100,250,500,1000, 2500 and $5000 \mu \mathrm{g}$ per plate with S9 mix, and 50,100, 250, 500, 1000 and 2500 without S9 mix in all tester strains.

\section{Small molecule $X$-ray structure determination and refinement of DSM421}

Compound DSM421 was crystallized from benzene. A colorless prism, measuring $0.30 \times 0.15 \times 0.12$ $\mathrm{mm}^{3}$ was mounted on a loop with oil. Data was collected at $-173{ }^{\circ} \mathrm{C}$ on a Bruker APEX II single crystal X-ray diffractometer, Mo-radiation. Crystal-to-detector distance was $40 \mathrm{~mm}$ and exposure time was 240 seconds per frame for all sets. The scan width was $0.5^{\circ}$. Data collection was $99.7 \%$ complete to $25^{\circ}$ in $\Theta$. A total of 15447 reflections were collected covering the indices, $\mathrm{h}=-11$ to $11, \mathrm{k}=-15$ to $15,1=-15$ to 16.5613 reflections were symmetry independent and the $\mathrm{R}_{\mathrm{int}}=0.0648$ indicated that the data was of appropriate quality. Indexing and unit cell refinement indicated a triclinic lattice. The space group was found to be $\mathrm{P} \overline{1}$ (No.2). The data were integrated and scaled using SAINT, SADABS within the APEX2 software package by Bruker. ${ }^{8}$ Solution by direct methods (SHELXS, SIR97 ${ }^{9,10}$ ) produced a complete heavy atomphasing model consistent with the proposed structure. The structure was completed by difference Fourier synthesis with SHELXL97. ${ }^{11,12}$ Scattering factors are from Waasmair and Kirfel. ${ }^{13}$ Hydrogen atoms were placed in geometrically idealized positions and constrained to ride on their parent atoms with $\mathrm{C}---\mathrm{H}$ distances in the range 0.95-1.00 Angstrom. Isotropic thermal parameters $\mathrm{U}_{\mathrm{eq}}$ were fixed such that they were $1.2 \mathrm{U}_{\text {eq }}$ of their parent atom $\mathrm{U}_{\text {eq }}$ for $\mathrm{CH}$ 's and $1.5 \mathrm{U}_{\text {eq }}$ of their parent atom $\mathrm{U}_{\text {eq }}$ in case of methyl groups. All non-hydrogen atoms were refined anisotropically by full-matrix least-squares.

\section{Chemistry General Methods}

All reagents and starting materials were obtained from commercial suppliers and used without further purification. Ethyl acetoacetate was purchased from Sigma-Aldrich, MO, USA. Aminoguanidine Hydrochloride was purchased from TCI chemicals, OR, USA. Ethyl 2,2-difluoropropionate was purchased from Oakwood Products, Inc. SC, USA. 5-Amino-2-trifluoromethylpyridine was purchased from Combi-Blocks, Inc. CA, USA. 
Reaction progress was monitored by thin layer chromatography (TLC) on preloaded silica gel $60 \mathrm{~F}_{254}$ plates. Visualization was achieved with UV light and iodine vapor. Flash chromatography was carried out using prepacked Teledyne Isco Redisep Rf silica-gel columns as the stationary phase and analytical grade solvents as the eluent unless otherwise stated. ${ }^{1} \mathrm{H}$ nuclear magnetic resonance (NMR) spectra were recorded on an Avance 301 Bruker instrument operating at $300.10 \mathrm{MHz}$ and Avance ${ }^{\mathrm{III}}$ Bruker instrument operating at $400.31 \mathrm{MHz}$ at ambient temperature. Chemical shifts are reported in parts per million $(\delta)$ and coupling constants in $\mathrm{Hz}$. ${ }^{1} \mathrm{H} \mathrm{NMR}$ spectra were referenced to the residual solvent peaks as internal standards (7.26 ppm for $\mathrm{CDCl}_{3}, 2.50 \mathrm{ppm}$ for DMSO- $\mathrm{d}_{6}$, and $3.34 \mathrm{ppm}$ for $\mathrm{CD}_{3} \mathrm{OD}$ ). Spin multiplicities are described as s (singlet), brs (broad singlet), $\mathrm{d}$ (doublet), $\mathrm{t}$ (triplet) and $\mathrm{m}$ (multiplet). Total ion current traces were obtained for electrospray positive and negative ionization (ES+/ES-) on a Bruker Esquire Liquid Chromatograph-Ion trap mass spectrometer. Analytical chromatographic conditions used for the LC/MS analysis: Column, Zorbax Extend C18 from Agilent technologies, $2.1 \times 100 \mathrm{~mm}$. The stationary phase particle size is $3.5 \mu \mathrm{M}$. Solvents were A, aqueous solvent $=$ water $+5 \%$ acetonitrile $+1 \%$ acetic acid; $\mathrm{B}$, organic solvent $=$ acetonitrile $+1 \%$ acetic acid; Methods, 14 min run time $(0-10$ min $20-100 \% \mathrm{~B}$, flow rate- $0.275 \mathrm{~mL} / \mathrm{min} ; 10-12 \mathrm{~min} 100 \% \mathrm{~B}$, flow rate- $0.350 \mathrm{~mL} / \mathrm{min} ; 12-12.50 \mathrm{~min} 100-20 \% \mathrm{~B}$, flow rate- $0.350 \mathrm{~mL} / \mathrm{min} ; 12.50-14.0 \mathrm{~min} 20 \% \mathrm{~B}$, flow rate- $0.350 \mathrm{~mL} / \mathrm{min}$ ). The following additional parameters were used: injection volume $(10 \mu \mathrm{L})$, column temperature $\left(30{ }^{\circ} \mathrm{C}\right)$, UV wavelength range $(254-330 \mathrm{~nm})$. The purity of all tested compounds was $\geq 95 \%$ using the analytical method described above unless stated otherwise. Analytical HPLC analyses were performed on a Supelco SupelcoSIL LC18 column $(5 \mu \mathrm{m}, 4.6 \mathrm{~mm}$ x $25 \mathrm{~cm})$ with a linear elution gradient ranging from 0-100\% ACN over 27 min, using a SupelcoSIL LC18 column $(5 \mu \mathrm{m}, 4.6 \mathrm{~mm}$ $\mathrm{x} 25 \mathrm{~cm})$ at a flow rate of $1 \mathrm{~mL} / \mathrm{min}$.

\section{Chemical Synthesis of DSM421 and analogs}

Scheme S1. Overall synthetic route for compounds described in Table 1.

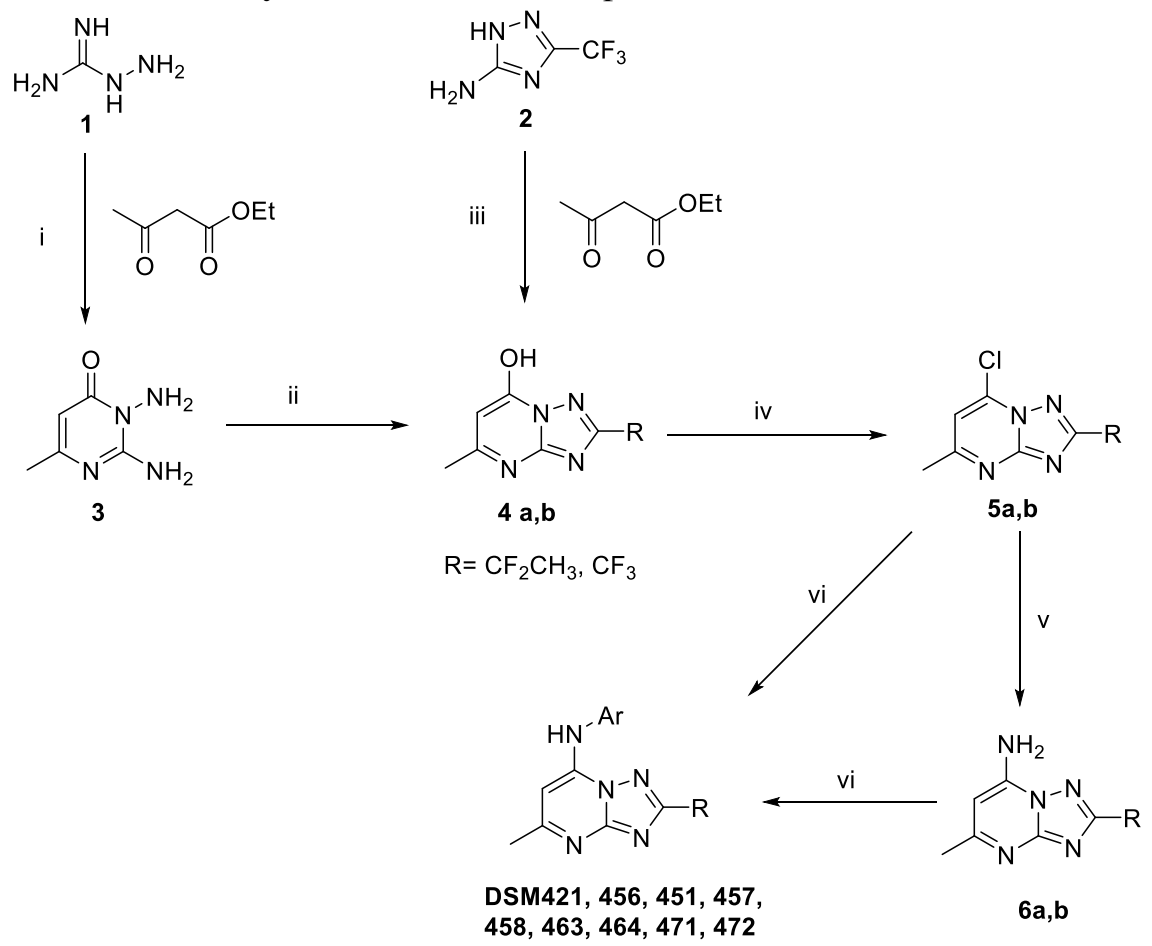

Reagents and conditions: (i) a) $\mathrm{NaOH}$, EtOH, $3 \mathrm{~h}$ at RT; (or) b) NaOEt, EtOH reflux $5 \mathrm{~h}$, overnight at RT; (ii) Ethyl 2,2 difluoropropanoate, NaOEt, $30 \mathrm{~min}, \mathrm{RT},(1.5-3) \mathrm{h}, 80^{\circ} \mathrm{C}$; (iii) $\mathrm{AcOH}$, reflux, $8 \mathrm{~h}$; (iv) reflux in $\mathrm{POCl}_{3}, 1-2 \mathrm{~h}$; (v) $\mathrm{NH}_{3}, 1,4-$ dioxane, $0-25^{\circ} \mathrm{C}, 8 \mathrm{~h}$; vi) appropriate amine, EtOH, 5-8 h, RT or $50^{\circ} \mathrm{C}$; (or) Pd(OAc) 2 , BINAP, NaOtBu, Toulene, MW, $130^{\circ} \mathrm{C}, 40 \mathrm{~min}$; (or) t-BuXphos palladacycle, NaOtBu, THF, $60^{\circ} \mathrm{C}, 3 \mathrm{~h}$. 
2-(1,1-Difluoroethyl)-5-methyl-N-(6-(trifluoromethyl)pyridin-3-yl)-[1,2,4]triazolo[1,5-a]pyrimidin-7amine (DSM421). To a suspension of intermediate $5 \mathbf{a}(0.23 \mathrm{~g}, 1 \mathrm{mmol})$ in ethanol $(5 \mathrm{~mL}), 5$-Amino-2-

trifluoromethylpyridine $(0.16 \mathrm{~g}, 1 \mathrm{mmol})$ was added and the mixture was stirred at RT or at $50{ }^{\circ} \mathrm{C}$ until the reaction reached completion. Ammonia solution $7 \mathrm{~N}$ in methanol $(50 \mu \mathrm{l})$ was added and solvent was removed in vacuo and the crude mixture was purified by flash chromatography (silica gel, eluting with hexane:EtOAc mixtures from 75:25 to 25:75\%) to yield DSM421. LCMS: (M+H) 358, RT. $2.88 \mathrm{~min}, 99.76 \%$ (Max). ${ }^{1} \mathrm{H} \mathrm{NMR} \mathrm{(300} \mathrm{MHz,}$ $\left.\mathrm{CD}_{3} \mathrm{OD}\right) \delta(\mathrm{ppm}): 8.86(\mathrm{~s}, 1 \mathrm{H}), 8.17(\mathrm{~d}, J=8.2 \mathrm{~Hz}, 1 \mathrm{H}), 7.96(\mathrm{~d}, J=8.5 \mathrm{~Hz}, 1 \mathrm{H}), 6.75(\mathrm{~s}, 1 \mathrm{H}), 2.57(\mathrm{~s}, 3 \mathrm{H}), 2.16(\mathrm{t}$, $J=18.85 \mathrm{~Hz}, 3 \mathrm{H})$. ESIMS $m / z: 359.4(\mathrm{MH})^{+}$. The structure was verified by crystallography (Fig. S3 and Table S19).

2-(1,1-Difluoroethyl)-5-methyl-N-(5-(trifluoromethyl)pyridin-2-yl)-[1,2,4]triazolo[1,5-a]pyrimidin-7amine (DSM456). To a solution of $\mathbf{5 a}(0.1 \mathrm{~g}, 0.43 \mathrm{mmol})$ and 5-(trifluoromethyl)pyridin-2-amine $(0.056 \mathrm{~g}, 0.34$ $\mathrm{mmol})$ in toluene $(10 \mathrm{~mL})$ was added sodium t-butoxide $(0.12 \mathrm{~g}, 2.19 \mathrm{~mol})$ and degassed under nitrogen for $5 \mathrm{~min}$. To that purged reaction mixture $\mathrm{Pd}(\mathrm{OAc})_{2}(0.014 \mathrm{~g}, 0.0068 \mathrm{mmol})$ and $\mathrm{BINAP}(0.016 \mathrm{~g}, 0.0258 \mathrm{mmol})$ were added and degassed under nitrogen for $5 \mathrm{~min}$ and heated under microwave for $40 \mathrm{~min}$ at $130^{\circ} \mathrm{C}$. After completion of the reaction, reaction mixture was diluted with EtOAc and water, layers were separated and aqueous layer was extracted with EtOAc. The combined organic layers were washed with brine solution and organic layer was dried over $\mathrm{Na}_{2} \mathrm{SO}_{4}$, filtered and concentrated. The crude product was purified by column chromatography using dichloromethane and 1-10\% methanol as eluents to yield DSM456. LCMS: (M+H) 359, RT. $2.82 \mathrm{~min}, 95.16 \%$ (Max). ${ }^{1} \mathrm{H}$ NMR: $(400 \mathrm{MHz}, \mathrm{MeOD}): \delta 8.81(\mathrm{~s}, 1 \mathrm{H}), 8.37(\mathrm{~s}, 1 \mathrm{H}), 8.12(\mathrm{dd}, J=2.32,8.76 \mathrm{~Hz}, 1 \mathrm{H}), 7.64(\mathrm{~d}, J=$ $8.72 \mathrm{~Hz}, 1 \mathrm{H}), 2.70(\mathrm{~s}, 3 \mathrm{H}), 2.13-2.22(\mathrm{~m}, 3 \mathrm{H})$.

2-(1,1-Difluoroethyl)-5-methyl-N-(2-(trifluoromethyl)pyrimidin-5-yl)-[1,2,4]triazolo[1,5a]pyrimidin-7-amine (DSM458). To a solution of $\mathbf{5 a}(0.17 \mathrm{~g}, 0.73 \mathrm{mmol})$ and 2-(trifluoromethyl)pyrimidin-5amine $(0.119 \mathrm{~g}, 0.732 \mathrm{mmol})$ in THF $(10 \mathrm{~mL})$ was added sodium t-butoxide $(0.21 \mathrm{~g}, 2.19 \mathrm{mmol})$ and degassed under nitrogen for $10 \mathrm{~min}$. To this purged reaction mixture t-BuXphos Palladacycle $(0.05 \mathrm{~g}, 0.0732 \mathrm{mmol})$ was added and degassed under nitrogen for $5 \mathrm{~min}$ and heated the reaction mixture to $60^{\circ} \mathrm{C}$ for $3 \mathrm{~h}$. After completion of the reaction, reaction mixture was cooled, diluted with EtOAc and water, layers were separated and aqueous layer was extracted with EtOAc. The combined organic layers were washed with brine solution and organic layer was dried over $\mathrm{Na}_{2} \mathrm{SO}_{4}$, filtered and concentrated. The crude product was purified by column chromatography using dichloromethane and 1-10\% of methanol as eluents to obtain DSM458. LCMS: (M+H) 360, RT. 2.54 min, 99.71\% (Max). ${ }^{1} \mathrm{H}$ NMR: (400 MHz, MeOD): $\delta 9.09$ (s, 2H), 6.83 (s, 1H), 2.57 (s, 3H), 2.12-2.16 (m, 3H).

2-(1,1-Difluoroethyl)-5-methyl-N-(5-(trifluoromethyl)pyrimidin-2-yl)-[1,2,4]triazolo[1,5-

a]pyrimidin-7-amine (DSM463). To a solution of 5a $(0.15 \mathrm{~g}, 0.64 \mathrm{mmol})$ and 5-(trifluoromethyl)pyrimidin-2amine $(0.084 \mathrm{~g}, 0.51 \mathrm{mmol})$ in toluene $(10 \mathrm{~mL})$ was added sodium t-butoxide $(0.186 \mathrm{~g}, 1.9 \mathrm{mmol})$ and degassed under nitrogen for $5 \mathrm{~min}$. To that purged reaction mixture, $\mathrm{Pd}(\mathrm{OAc}) 2(0.0218 \mathrm{~g}, 0.01 \mathrm{mmol})$ and BINAP $(0.024 \mathrm{~g}$, $0.038 \mathrm{mmol}$ ) were added and degassed under nitrogen for $5 \mathrm{~min}$ and heated at $\mathrm{MW}$ for $40 \mathrm{~min}$ at $130^{\circ} \mathrm{C}$. After completion of the reaction, reaction mixture was diluted with EtOAc and water, layers were separated and aqueous layer was extracted with EtOAc. The combined organic layers were washed with brine solution and organic layer was dried over $\mathrm{Na} 2 \mathrm{SO} 4$, filtered and concentrated. The crude product was purified by column chromatography using dichloromethane and 1-10\% of methanol as eluents to obtain DSM463 (0.070 g, 30\%). LCMS: (M+H) 360, RT. $2.61 \mathrm{~min}, 99.52 \%$ (Max). ${ }^{1} \mathrm{H}$ NMR: (400 MHz, MeOD): $\delta 9.10$ (s, 2H), 8.31 (s, 1H), $2.74(\mathrm{~s}, 3 \mathrm{H}), 2.17-2.10(\mathrm{~m}, 3 \mathrm{H})$.

5-Methyl-2-(trifluoromethyl)-N-(6-(trifluoromethyl)pyridin-3-yl)-[1,2,4]triazolo[1,5-a]pyrimidin-7amine (DSM464). To a solution of $\mathbf{5 b}(0.1 \mathrm{~g}, 0.423 \mathrm{mmol})$ in ethanol $(10 \mathrm{~mL})$, 6-(trifluoromethyl)pyridin-3amine $(0.068 \mathrm{~g}, 0.423 \mathrm{mmol})$ was added and heated the reaction mixture to $50^{\circ} \mathrm{C}$ for $1 \mathrm{~h}$. After completion of the reaction, solvent was removed under reduced pressure, crude product dissolved in EtOAc and organic layer 
washed with $10 \% \mathrm{NaHCO}_{3}$ solution, water and brine solution. The organic layer was dried over anhydrous $\mathrm{Na}_{2} \mathrm{SO}_{4}$, filtered and concentrated. The crude product was purified by column chromatography using dichloromethane and 1-10\% of methanol as eluents to obtain DSM464 (0.064 g, 42\%)._LCMS: (M+H) 363.2, RT. $2.57 \mathrm{~min}, 99.05 \%$ (Max). ${ }^{1} \mathrm{H}$ NMR: (400 MHz, MeOD): $\delta 8.86(\mathrm{~s}, 1 \mathrm{H}), 8.17(\mathrm{~d}, J=7.00 \mathrm{~Hz}, 1 \mathrm{H}), 7.97(\mathrm{~d}, J=$ $8.48 \mathrm{~Hz}, 1 \mathrm{H}), 6.81(\mathrm{~s}, 1 \mathrm{H}), 2.59(\mathrm{~s}, 3 \mathrm{H})$.

5-Methyl-2-(trifluoromethyl)-N-(2-(trifluoromethyl)pyrimidin-5-yl)-[1,2,4]triazolo[1,5-a]pyrimidin7-amine (DSM472). To a solution of $\mathbf{5 b}(0.15 \mathrm{~g}, 0.63 \mathrm{mmol})$ and 2-(trifluoromethyl)pyrimidin-5-amine $(0.082 \mathrm{~g}$, $0.58 \mathrm{mmol})$ in THF $(10 \mathrm{~mL})$ was added sodium t-butoxide $(0.182 \mathrm{~g}, 1.9 \mathrm{mmol})$ and degassed under nitrogen for $10 \mathrm{~min}$. To this purged reaction mixture t-BuXphos Palladacycle $(0.043 \mathrm{~g}, 0.063 \mathrm{mmol})$ was added and degassed under nitrogen for $5 \mathrm{~min}$ and heated the reaction mixture to $60^{\circ} \mathrm{C}$ for $3 \mathrm{~h}$. After completion of the reaction, reaction mixture was cooled, diluted with EtOAc and water, layers were separated and aqueous layer was extracted with EtOAc. The combined organic layers were washed with brine solution and organic layer was dried over $\mathrm{Na}_{2} \mathrm{SO}_{4}$, filtered and concentrated. The crude product was purified by column chromatography using dichloromethane and 1-10\% of methanol to obtain DSM472 (0.10 g, 43\%) LCMS: (M+H) 364, RT. 2.52 min, 99.34\% (Max). ${ }^{1} \mathrm{H}$ NMR: (400 MHz, MeOD $\delta 9.12$ (s, 2H), 6.93 (s, 1H), 2.60 (s, 3H).

DSM451, DSM457 and DSM471 were prepared by an alternate route starting from 2-(1,1-difluoroethyl)5-methyl-[1,2,4]triazolo[1,5-a]pyrimidin-7-amine $\quad(\mathbf{6 a}) \quad$ or $\quad 5$-methyl-2-(trifluoromethyl)-[1,2,4]triazolo[1,5a]pyrimidin-7-amine (6b) (Scheme S1), which were prepared as follows: A solution of 5a or $5 \mathbf{b}$ (1.2 mmol) in 1,4-dioxane $(5 \mathrm{~mL})$ was cooled to $0^{\circ} \mathrm{C}$, purged with ammonia gas for $10 \mathrm{~min}$ and stirred in sealed tube for $8 \mathrm{~h}$ at $25^{\circ} \mathrm{C}$. After completion of the reaction, solvent was removed under reduced pressure and dried to get pure $6 \mathbf{a}$ or 6b (0.27 g (100\%). LCMS (6a): (M+H) 214, RT. 1.62 min, 96.59\% (Max). ${ }^{1} \mathrm{H}$ NMR (6a): (300 MHz, DMSO d6): $\delta 8.16(\mathrm{brs}, 2 \mathrm{H}), 6.27(\mathrm{~s}, 1 \mathrm{H}), 2.38(\mathrm{~s}, 3 \mathrm{H}), 2.00-2.06(\mathrm{~m}, 3 \mathrm{H})$. LCMS (6b): $(\mathrm{M}+\mathrm{H}) 218$, RT. $0.7 \mathrm{~min}$, 95.78\% ${ }^{1} \mathrm{H}$ NMR (6b): (300 MHz, DMSO d6): $\delta 8.32$ (brs, 2H), 6.29 (s, 1H), 2.26 (s, 3H).

2-(1,1-Difluoroethyl)-5-methyl-N-(5-(trifluoromethyl)pyridin-3-yl)-[1,2,4]triazolo[1,5-a]pyrimidin-7amine (DSM451). To a solution of $6 \mathbf{6}(0.12 \mathrm{~g}, 0.56 \mathrm{mmol})$ and 3-bromo-5-trifluoromethyl-pyridine $(0.12 \mathrm{~g}$, $0.563 \mathrm{mmol})$ in THF $(10 \mathrm{~mL})$ was added sodium t-butoxide $(0.16 \mathrm{~g}, 1.69 \mathrm{mmol})$ and degassed under nitrogen for $10 \mathrm{~min}$. To this purged reaction mixture, $\mathrm{t}$-BuXphos Palladacycle $(0.038 \mathrm{~g}, 0.0563 \mathrm{~mol})$ was added and degassed under nitrogen for $5 \mathrm{~min}$ and heated the reaction mixture to $60^{\circ} \mathrm{C}$ for $3 \mathrm{~h}$. After completion of the reaction, reaction mixture was cooled, diluted with EtOAc and water, layers were separated and aqueous layer was extracted with EtOAc. The combined organic layers were washed with brine solution and organic layer was dried over $\mathrm{Na}_{2} \mathrm{SO}_{4}$, filtered and concentrated. The crude product was purified by column chromatography using dichloromethane and 1-10\% methanol as eluents to yield DSM451._LCMS: (M+H) 359.4, RT. 2.91 min, 99.13\% (Max). ${ }^{1} \mathrm{H}$ NMR: $(400 \mathrm{MHz}, \mathrm{MeOD}): \delta 8.99$ (s, 1H), 8.87 (s, 1H), 8.29 (s, 1H), 6.64 (s, 1H), 2.56 (s, 3H), 2.11$2.20(\mathrm{~m}, 3 \mathrm{H})$.

2-(1,1-Difluoroethyl)-5-methyl-N-(2-(trifluoromethyl)pyridin-4-yl)-[1,2,4]triazolo[1,5-a]pyrimidin-7amine (DSM457). To a solution of $\mathbf{6 a}(0.12 \mathrm{~g}, 0.56 \mathrm{mmol})$ and 4-chloro-2-(trifluoromethyl)pyridine $(0.102 \mathrm{~g}$, $0.563 \mathrm{mmol})$ in THF $(10 \mathrm{~mL})$ was added sodium t-butoxide $(0.16 \mathrm{~g}, 1.69 \mathrm{mmol})$ and degassed under nitrogen for $10 \mathrm{~min}$. To this purged reaction mixture t-BuXphos Palladacycle $(0.038 \mathrm{~g}, 0.0563 \mathrm{mmol})$ was added and degassed under nitrogen for $5 \mathrm{~min}$ and heated the reaction mixture to $60^{\circ} \mathrm{C}$ for $3 \mathrm{~h}$. After completion of the reaction, reaction mixture was cooled, diluted with EtOAc and water, layers were separated and aqueous layer was extracted with EtOAc. The combined organic layers were washed with brine solution and organic layer was dried over $\mathrm{Na}_{2} \mathrm{SO}_{4}$, filtered and concentrated. The crude product was purified by column chromatography using dichloromethane and 1-10\% of methanol as eluents to yield DSM457. LCMS: (M+H) 359.4, RT. 2.88 min, 99.21\% (Max). ${ }^{1} \mathrm{H}$ NMR: (400 MHz, MeOD): $\delta 8.73$ (d, J = 5.44 Hz, 1H), 7.91 (s, 1H), 7.81 (s, 1H), 7.09 (s, 1H), $2.65(\mathrm{~s}, 3 \mathrm{H}), 2.11-2.21(\mathrm{~m}, 3 \mathrm{H}) .(\mathrm{M}+\mathrm{H}) 359.4$ 
5-Methyl-2-(trifluoromethyl)-N-(5-(trifluoromethyl)pyridin-2-yl)-[1,2,4]triazolo[1,5-a]pyrimidin-7amine (DSM471). To a solution of $6 \mathbf{b}(0.18 \mathrm{~g}, 0.85 \mathrm{mmol})$ and 2-bromo-5-trifluoromethyl-pyridine $(0.154 \mathrm{~g}, 0$. $68 \mathrm{mmol})$ in THF $(10 \mathrm{~mL})$ was added sodium t-butoxide $(0.24 \mathrm{~g}, 2.04 \mathrm{mmol})$ and degassed under nitrogen for 10 min. To this purged reaction mixture t-BuXphos Palladacycle $(0.058 \mathrm{~g}, 0.085 \mathrm{~mol})$ was added and degassed under nitrogen for $5 \mathrm{~min}$ and heated the reaction mixture to $60^{\circ} \mathrm{C}$ for $3 \mathrm{~h}$. After completion of the reaction, reaction mixture was cooled, diluted with EtOAc and water, layers were separated and aqueous layer was extracted with EtOAc. The combined organic layers were washed with brine solution and organic layer was dried over $\mathrm{Na}_{2} \mathrm{SO}_{4}$, filtered and concentrated. The crude product was purified by column chromatography using dichloromethane and 1-10\% of methanol as eluents to obtain DSM471 (0.12 g, 40\%)._LCMS: (M+H) 363.2, RT. $3.36 \mathrm{~min}, 99.11 \%$ (Max). ${ }^{1} \mathrm{H}$ NMR: (400 MHz, MeOD): $\delta 8.81$ (s, 1H), 8.45 (s, 1H), 8.13 (dd, $J=2.2 \& 8.80, \mathrm{~Hz}$, $1 \mathrm{H}), 7.66(\mathrm{~d}, J=8.72 \mathrm{~Hz}, 1 \mathrm{H}), 2.72(\mathrm{~s}, 3 \mathrm{H})$.

(2-(1,1-Difluoroethyl)-7-((6-(trifluoromethyl)pyridin-3-yl)amino)-[1,2,4]triazolo[1,5-a]pyrimidin-5-

yl)methanol (DSM565). DSM565 was prepared as described in Scheme S2 and has the following characteristics. LC-MS APCI: Calculated for C14H11F5N6O 374.28 Observed $m / z$. $[\mathrm{M}+1]^{+:} 375.2 ; 99.27 \%$. HPLC purity: 98.40\%. ${ }^{1} \mathrm{H}$ NMR (400 MHz, DMSO-d 6 ): $\delta 10.90(\mathrm{~s}, 1 \mathrm{H}), 8.88(\mathrm{~s}, 1 \mathrm{H}), 8.14(\mathrm{~d}, \mathrm{~J}=7.0 \mathrm{~Hz}, 1 \mathrm{H}), 8.04(\mathrm{~d}, \mathrm{~J}=7.0$ $\mathrm{Hz}, 1 \mathrm{H}), 6.86(\mathrm{~s}, 1 \mathrm{H}), 5.68(\mathrm{t}, \mathrm{J}=5.8 \mathrm{~Hz}, 1 \mathrm{H}), 4.53(\mathrm{~d}, \mathrm{~J}=6.0 \mathrm{~Hz}, 2 \mathrm{H}), 2.10-2.19(\mathrm{~m}, 3 \mathrm{H})$.

\section{Synthesis of DSM565}

Scheme S2: Synthesis of DSM565<smiles>CCOC(=O)CC(=O)CCl</smiles>

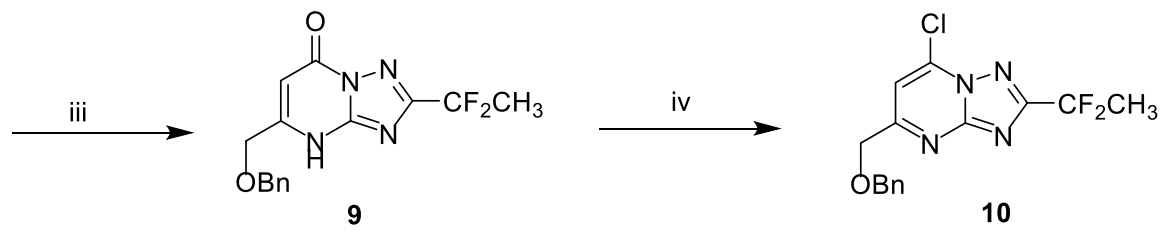

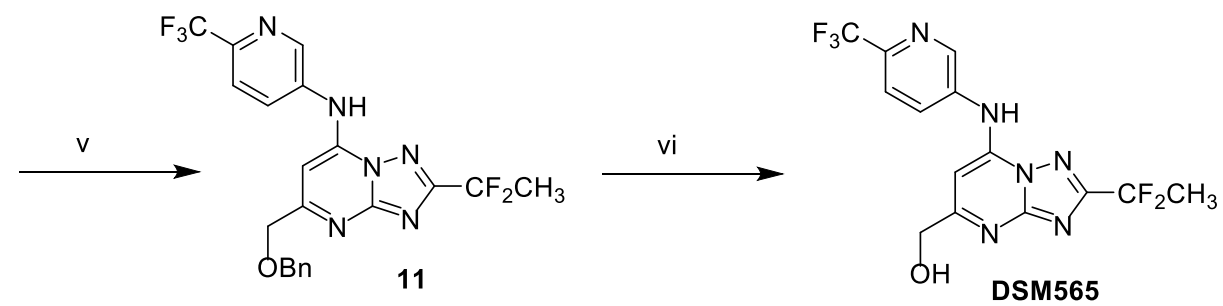

Reagents and conditions: i) NaH, THF, R.T. $16 \mathrm{~h}$ ii) DMA, DIPEA, $110^{\circ} \mathrm{C}, 12 \mathrm{~h}$ iii) Ethyl 2,2-difluropropionate, NaOEt, $\mathrm{EtOH}, 90^{\circ} \mathrm{C}, 6 \mathrm{~h}$ iv) $\mathrm{POCl}_{3}$, reflux, $1 \mathrm{~h}$ v) 5-Amino-2-(trifluoromethyl)pyridine, $\mathrm{NaH}, \mathrm{DMF}, \mathrm{RT}, 3 \mathrm{~h}$ vi) $\mathrm{BCl}_{3}\left(1 \mathrm{M} \mathrm{CH}_{2} \mathrm{Cl}_{2}\right),-70^{\circ} \mathrm{C}, 20 \mathrm{~min}$

Ethyl 4-(benzyloxy)-3-oxobutanoate (7): To a suspension of $\mathrm{NaH}$ (60 percent in mineral oil, $2.93 \mathrm{~g}$, $73.16 \mathrm{mmol})$ in anhydrous THF (50 mL) was added benzyl alcohol (3.95 g, $36.58 \mathrm{mmol})$ dropwise over $20 \mathrm{~min}$. After stirring for $2 \mathrm{~h}$, ethyl chloroacetoacetate $(6 \mathrm{~g}, 36.58 \mathrm{mmol})$ was added dropwise over $15 \mathrm{~min}$ and the reaction mixture was further stirred at RT for $16 \mathrm{~h}$. After completion of the reaction, the reaction mixture was slowly quenched with $2 \mathrm{~N}$ aq. $\mathrm{HCl}$. The aqueous layer was separated and extracted with ethyl acetate $(2 \mathrm{x} 200$ 
$\mathrm{mL})$. The combined EtOAc layer were dried over anhydrous sodium sulfate and concentrated under vacuo. The concentrated crude oil was purified by flash chromatography on silica gel using hexane/ethyl acetate to afford 7 ( 8 $\mathrm{g}, 92.5 \%)$ as pale yellow oil.

2,3-Diamino-6-(benzyloxymethyl)pyrimidin-4(3H)-one (8): A reaction mixture of amino guanidine hydrochloride ( $3.72 \mathrm{~g}, 33.85 \mathrm{mmol}), 7(8 \mathrm{~g}, 33.85 \mathrm{mmol})$ and DIPEA (12 mL, $67.72 \mathrm{mmol})$ in DMA $(20 \mathrm{~mL})$ was stirred at $110{ }^{\circ} \mathrm{C}$ for $12 \mathrm{~h}$ in a sealed tube. Reaction mixture was cooled to room temperature. Solid precipitated out was filtered and washed with diethyl ether to afford $\mathbf{8}(1.5 \mathrm{~g}, 18 \%)$ as off white solid.

5-(Benzyloxymethyl)-2-(1,1-difluoroethyl)-[1,2,4]triazolo[1,5-a]pyrimidin-7(4H)-one (9): 8 (1.5 $\mathrm{g}, \quad 6.09$ mmol) was added to a stirred solution of NaOEt prepared freshly from sodium $(0.35 \mathrm{~g}, 15.23 \mathrm{mmol})$ and ethanol (25 mL). Then, reaction mixture was heated at $90{ }^{\circ} \mathrm{C}$ for 30 minutes. The reaction mixture was cooled down to room temperature. The ethyl 2, 2-difluoropropanoate $(2.1 \mathrm{~g}, 15.23 \mathrm{mmol})$ was added to cooled reaction mixture at RT and stirred at room temperature for $30 \mathrm{~min}$. The resulting reaction mixture was heated at $90{ }^{\circ} \mathrm{C}$ for $6 \mathrm{~h}$. The reaction mixture was concentrated to dryness and water $(100 \mathrm{~mL})$ was added. The $\mathrm{pH}$ was adjusted to 4 by addition of $2 \mathrm{~N} \mathrm{HCl}$ solution to above reaction mixture. The precipitated solid was filtered, washed with water and dried under vacuum to afford compound $\mathbf{9}(1.5 \mathrm{~g}, 77 \%)$ as a white solid.

5-(Benzyloxymethyl)-7-chloro-2-(1,1-difluoroethyl)-[1,2,4]triazolo[1,5-a]pyrimidine $\quad(10): \quad A$ suspension of $\mathbf{9}$ (1.5 g, $4.69 \mathrm{mmol})$ in phosphorus oxychloride $(1.4 \mathrm{~g}, 9.37 \mathrm{mmol})$ was refluxed for $1 \mathrm{~h}$. Ice cold water was added slowly to the reaction mixture and neutralized with addition of solid $\mathrm{Na}_{2} \mathrm{CO}_{3}$. The resulting product was extracted with dichloromethane $(3 \times 75 \mathrm{~mL})$. The combined organic layer was washed with brine, dried over anhydrous $\mathrm{Na}_{2} \mathrm{SO}_{4}$ and concentrated. The concentrated crude product was purified by flash chromatography using $50 \%$ ethyl acetate in hexane to afford $\mathbf{1 0}(0.7 \mathrm{~g}, 44 \%)$ as white solid.

5-(Benzyloxymethyl)-2-(1,1-difluoroethyl)-N-(6-(trifluoromethyl)pyridin-3-yl)-[1,2,4]triazolo[1,5a]pyrimidin-7-amine (11): To a stirred solution of 6-(trifluoromethyl) pyridin-3-amine $(0.332 \mathrm{~g}, 2.07 \mathrm{mmol})$ in DMF (10 mL) was added $\mathrm{NaH}(60$ percent in mineral oil, $0.17 \mathrm{~g}, 4.13 \mathrm{mmol})$ and stirred for $20 \mathrm{~min}$ at room temperature. Then, $\mathbf{1 0}(0.7 \mathrm{~g}, 2.07 \mathrm{mmol})$ was added to stirred reaction mixture at room temperature and continued stirring for 3 hours at same temperature. The reaction mixture was poured in to $\mathrm{NH}_{4} \mathrm{Cl}$ solution and extracted with ethyl acetate $(2 \times 25 \mathrm{~mL})$. Separated organic layer was washed with brine solution, dried over $\mathrm{Na}_{2} \mathrm{SO}_{4}$ and concentrated. The concentrated residue was purified by silica gel column using 0-50\% EtOAc in hexane to afford $5(0.3 \mathrm{~g}, 31 \%)$ as off white solid.

(2-(1,1-Difluoroethyl)-7-(6-(trifluoromethyl)pyridin-3-ylamino)-[1,2,4]triazolo[1,5-a]pyrimidin-5-

yl)methanol (DSM565): To a stirred solution of $11(0.3 \mathrm{~g}, 0.86 \mathrm{mmol})$ in anhydrous dichloromethane $(15 \mathrm{~mL})$ was added borontrichloride $\left(3 \mathrm{~mL} ; 1 \mathrm{M}\right.$ in dichloromethane) at $-70{ }^{\circ} \mathrm{C}$. The temperature was maintained for 20 min. After that dichloromethane: methanol (1:1) was added to the reaction mixture very slowly to quench the reaction mixture. Triethylamine $(10 \mathrm{~mL})$ was added to the quenched reaction mixture after 10 min and warmed to room temperature. Then, the resulting reaction mixture was concentrated under vacuum. The concentrated crude product was purified by preparative HPLC to afford product DSM565 $(0.07 \mathrm{~g}, 29 \%)$ as a white solid.

LC-MS APCI: Calculated for C14H11F5N6O 374.28 Observed $m / z[\mathrm{M}+1]^{+:} 375.2 ; 99.27 \%$. HPLC purity: $98.40 \%$.

${ }^{1}$ H NMR (400 MHz, DMSO-d $)$ ) $\delta 10.90(\mathrm{~s}, 1 \mathrm{H}), 8.88(\mathrm{~s}, 1 \mathrm{H}), 8.14(\mathrm{~d}, \mathrm{~J}=7.0 \mathrm{~Hz}, 1 \mathrm{H}), 8.04(\mathrm{~d}, J=7.0$ $\mathrm{Hz}, 1 \mathrm{H}), 6.86(\mathrm{~s}, 1 \mathrm{H}), 5.68(\mathrm{t}, J=5.8 \mathrm{~Hz}, 1 \mathrm{H}), 4.53(\mathrm{~d}, J=6.0 \mathrm{~Hz}, 2 \mathrm{H}), 2.10-2.19(\mathrm{~m}, 3 \mathrm{H})$. 
Table S1. X-ray diffraction data and refinement statistics for PfDHODH bound to DSM421

\begin{tabular}{|c|c|}
\hline \multicolumn{2}{|l|}{ Data Collection } \\
\hline Resolution $(\AA ̊)$ & $50.00-2.15 \quad(2.19-2.15)$ \\
\hline Space group & $\mathrm{P}_{4}$ \\
\hline Cell dimensions $(\AA)$ & $a=b=86.4, c=138.6$ \\
\hline Wavelength $(\AA)$ & 0.97918 \\
\hline Unique reflections & $31,810(1,549)$ \\
\hline Data Completeness (\%) & $99.8(100)$ \\
\hline Redundancy & $12.4(10.2)$ \\
\hline $\mathrm{I} / \sigma$ & $41.1(1.0)$ \\
\hline $\mathrm{R}_{\text {merge }}(\%)^{\mathrm{a}}$ & $4.4(100)$ \\
\hline $\mathrm{R}_{\mathrm{pim}}(\%)^{\mathrm{b}}$ & $1.8(70.7)$ \\
\hline Wilson $B$-value $\left(\AA^{2}\right)$ & 26.0 \\
\hline \multicolumn{2}{|l|}{ Refinement } \\
\hline Resolution $(\AA)$ & $31.6-2.15 \quad(2.23-2.15)$ \\
\hline No. reflections $R_{\text {work }} / R_{\text {free }}$ & $26,506(565)$ \\
\hline Data Completeness (\%) & $83.5(17.8)$ \\
\hline $\mathrm{R}_{\text {work }} / \mathrm{R}_{\text {free }}(\%)$ & $18.1(26.8) / 21.9(25.9)$ \\
\hline Atoms (non-H protein/waters) & $83.5(17.8)$ \\
\hline R.m.s.d bond length $(\AA)$ & 0.003 \\
\hline R.m.s.d bond angles (deg.) & 0.76 \\
\hline Mean $B\left(\AA^{2}\right)$ (protein/ligand/water) & $47.6 / 40.8 / 34.3$ \\
\hline Mean $B$-value $\left(\AA^{2}\right)$ & 41.0 \\
\hline \multicolumn{2}{|l|}{ Ramachandran plot $^{c}$} \\
\hline Favored/Allowed (\%) & $96.6 / 3.4$ \\
\hline Missing residues & $159-161,344-355,566$ \\
\hline
\end{tabular}

Data for the outermost shell are given in parentheses.

${ }^{\mathrm{a}} R_{\text {merge }}=100 \Sigma_{\mathrm{h}} \Sigma_{\mathrm{i}} \mid I_{h, i}-\left\langle I_{h}\right\rangle / \Sigma_{h} \Sigma_{\mathrm{i}}\left\langle I_{h, i}\right\rangle$, where the outer sum (h) is over the unique reflections and the inner sum (i) is over the set of independent observations of each unique reflection.

${ }^{\mathrm{b}} R_{p i m}=100 \Sigma_{\mathrm{h}} \Sigma_{\mathrm{i}}\left[1 /\left(\mathrm{n}_{\mathrm{h}}-1\right)\right]^{1 / 2} \mid I_{h, i}-\left\langle I_{h}\right\rangle / \Sigma_{h} \Sigma_{\mathrm{i}}\left\langle I_{h, i}\right\rangle$, where $\mathrm{n}_{\mathrm{h}}$ is the number of observations of reflections $\mathbf{h}^{14}$

${ }^{\mathrm{c}}$ As defined by the validation suite MolProbity ${ }^{15}$ 
Table S2. DSM421 In vitro antimalarial activity

\begin{tabular}{|c|c|c|}
\hline P.falciparum & Resistance & $\mathbf{E C}_{50}(\mu \mathrm{M})$ \\
\hline \multicolumn{3}{|c|}{$\begin{array}{l}\text { Wild-type strains or strains resistant to clinically used } \\
\text { compounds }\end{array}$} \\
\hline NF54 & - & $26^{\mathrm{b}}$ \\
\hline $3 \mathrm{D} 7$ & - & $11^{\mathrm{a}}, 16^{\mathrm{a}}, 14^{\mathrm{a}}$ \\
\hline HB3 & Pyrimethamine & $8.8^{\mathrm{a}}, 21^{\mathrm{b}}$ \\
\hline K1 & $\begin{array}{l}\text { Chloroquine, } \\
\text { Pyrimethamine } \\
\text { Sulphadoxine } \\
\text { Cycloguanil }\end{array}$ & $34^{\mathrm{b}}$ \\
\hline TM90C2A & $\begin{array}{l}\text { Chloroquine } \\
\text { Pyrimethamine } \\
\text { Mefloquine }\end{array}$ & $13^{\mathrm{a}}, 18^{\mathrm{b}}$ \\
\hline 7G8 & $\begin{array}{l}\text { Chloroquine } \\
\text { Pyrimethamine } \\
\text { Cycloguanil }\end{array}$ & $36^{\mathrm{b}}$ \\
\hline D6 & Mefloquine & $19^{\mathrm{a}}, 13^{\mathrm{b}}$ \\
\hline $\mathrm{Dd} 2$ & $\begin{array}{l}\text { Chloroquine } \\
\text { Pyrimethamine } \\
\text { Sulphadoxine } \\
\text { Cycloguanil } \\
\text { Mefloquine }\end{array}$ & $16^{\mathrm{a}}, 20^{\mathrm{a}}, 61^{\mathrm{b}}$ \\
\hline $\mathrm{V} 1 / \mathrm{S}$ & $\begin{array}{l}\text { Chloroquine } \\
\text { Pyrimethamine } \\
\text { Sulphadoxine } \\
\text { Cycloguanil }\end{array}$ & $69^{\mathrm{b}}$ \\
\hline FCB & $\begin{array}{l}\text { Chloroquine } \\
\text { Cycloguanil } \\
\text { Mefloquine } \\
\text { Atovaquone }\end{array}$ & $79^{b}$ \\
\hline \multicolumn{3}{|c|}{ Dd2 selected for resistance to development candidates } \\
\hline Dd2 & ELQ-300 & $31^{\mathrm{b}}$ \\
\hline $\mathrm{Dd} 2$ & NITD609 & $34^{\mathrm{b}}$ \\
\hline $\mathrm{Dd} 2$ & SJ557733 & $14^{\mathrm{b}}$ \\
\hline $\mathrm{Dd} 2$ & GNF156 & $25^{\mathrm{b}}$ \\
\hline $\mathrm{Dd} 2(\mathrm{G} 181 \mathrm{C})$ & DSM265 & $400^{\mathrm{a}}$ (21-fold) \\
\hline $\begin{array}{l}\mathrm{Dd} 2 \\
(3 \mathrm{x} \text { DHODH) }\end{array}$ & DSM265 & $110^{\mathrm{a}}$ (7-fold) \\
\hline
\end{tabular}

Assays were performed in Albumax-based media. ${ }^{a}$ Assays performed at University of Washington in the Rathod lab using the Syber Green method with a minimum of three replicates per concentration were include in the dose response curves to determine $\mathrm{EC}_{50}{ }^{16}$. ${ }^{\mathrm{b}}$ Assays performed at Swiss TPH using the hypoxanthine based assay with a minimum of two replicates ${ }^{17}$. Drug sensitivities for clinically used drugs have been reported previously ${ }^{18}$. Strains resistant to clinical isolates have also been described in the following publications: ELQ-300 ${ }^{19}$, NITD609 ${ }^{20}$, SJ557733 ${ }^{21}$, GNF156 $6^{22}$ and DSM265 $5^{5}$, where line DF.R10clb(G181C mutation in DHODH) and 1D3 (PrCl1) containing a 3-fold gene amplification of DHODH were tested in the study. Values in parenthesis represent the fold resistance compare to the $\mathrm{Dd} 2$ control run in the Rathod lab. The average $\mathrm{EC}_{50}$ across all strains is $0.028 \pm 0.020 \mu \mathrm{M}$, where error is the standard deviation of the mean. 
Table S3. In vitro parasite reduction ratio (kill rate)

\begin{tabular}{|l|l|l|l|l|}
\hline Compound & Concentration & Lag (h) & Log PRR & $\begin{array}{l}\text { PCT } \\
99.9 \%(h)\end{array}$ \\
\hline DSM421 & $10 \mathrm{xEC}_{50}$ & 48 & 3.0 & 94 \\
\hline DSM265 & $10 \mathrm{xEC}_{50}$ & $24-48$ & 3.1 & 85 \\
\hline Art & $10 \mathrm{xEC}_{50}$ & 0 & $>4.8$ & $<24$ \\
\hline Ato & $10 \mathrm{xEC}_{50}$ & 48 & 2.9 & 81 \\
\hline Pyr & $10 \mathrm{xEC}_{50}$ & 24 & 3.7 & 57 \\
\hline Chl & $10 \mathrm{xEC}_{50}$ & 0 & 4.5 & 34 \\
\hline
\end{tabular}

Art, artemisinin; Ato, atovaquone; Pyr, pyrimethamine; Chl, chloroquine. Parasite Reduction Ratio (PRR), the log number of parasites killed per asexual life cycle (48 h), Lag Phase, time before parasite killing begins, and parasite clearance time (PCT), time to achieve $99.9 \%$ parasite kill. The $\mathrm{EC}_{50}$ for DSM421 in the $48 \mathrm{~h}$ growth assay was $0.043 \pm 0.006 \mu \mathrm{M}$. Data on the comparator compounds has been previously published ${ }^{5}$. 
Table S4A. Activity of DSM421 against $P$. falciparum and $P$. vivax field isolates.

\begin{tabular}{|l|l|l|l|l|l|l|}
\hline & \multicolumn{3}{|l|}{$\begin{array}{l}\text { P. falciparum lab lines } \\
(\mathrm{nM})\end{array}$} & \multicolumn{2}{l|}{$\begin{array}{l}\text { P. falciparum clinical } \\
\text { isolates (nM) }\end{array}$} & $\begin{array}{l}\text { P. vivax clinical isolates } \\
(\mathrm{nM})\end{array}$ \\
\hline Drug & FC27 & K1 & $\mathrm{n}$ & Median (range) & $\mathrm{n}$ & Median (range) \\
\hline Chloroquine & 32 & 212 & 9 & $86(36-129)$ & 12 & $147(13-255)$ \\
\hline Amodiaquine & 33 & 39 & 9 & $26(18-42)$ & 13 & $51(9.6-92)$ \\
\hline Piperaquine & 55 & 76 & 9 & $36(20-57)$ & 12 & $34(8.9-121)$ \\
\hline Mefloquine & 56 & 20 & 8 & $13(3.4-34)$ & 12 & $18(7.7-52)$ \\
\hline Artesunate & 3.6 & 5.1 & 8 & $2.4(0.6-7.5)$ & 12 & $0.8(0.3-5.7)$ \\
\hline DSM421 & $\mathbf{2 9 3}$ & $\mathbf{3 3 8}$ & $\mathbf{9}$ & $\mathbf{1 5 1}(\mathbf{8 5}-\mathbf{2 8 1})$ & $\mathbf{1 3}$ & $\mathbf{1 7 5}(\mathbf{5 6 - 3 7 3 )}$ \\
\hline
\end{tabular}

Data in parenthesis show the range of values. Ring stage parasites were exposed to drug for $48 \mathrm{~h}$ in this assay.

Two lab strains FC27 (CQ sensitive) and K1 (CQ resistant) were assayed as comparators using the same method.

Table S4B. Activity of DSM265 against $P$. falciparum and $P$. vivax field isolates.

\begin{tabular}{|l|l|l|l|l|l|l|}
\hline & \multicolumn{3}{|l|}{$\begin{array}{l}\text { P. falciparum lab lines } \\
\text { (nM) }\end{array}$} & \multicolumn{2}{l|}{$\begin{array}{l}\text { P. falciparum clinical } \\
\text { isolates }(\mathrm{nM})\end{array}$} & $\begin{array}{l}\text { P. vivax clinical isolates } \\
\text { (nM) }\end{array}$ \\
\hline Drug & FC27 & K1 & n & Median (range) & n & Median (range) \\
\hline Chloroquine & 23 & 194 & 27 & $101(33-238)$ & 34 & $44(12-298)$ \\
\hline Amodiaquine & 15 & 34 & 27 & $17(5.7-98)$ & 34 & $12(5.8-41)$ \\
\hline Piperaquine & 42 & 50 & 27 & $25(10-96)$ & 34 & $15(3.5-103)$ \\
\hline Mefloquine & 66 & 19 & 27 & $13(2.7-44)$ & 34 & $15(5.3-48)$ \\
\hline Artesunate & 11 & 9.6 & 19 & $2.6(1.4-18)$ & 26 & $2.9(0.8-13)$ \\
\hline DSM265 & $\mathbf{1 7 7}$ & $\mathbf{2 3 9}$ & $\mathbf{1 2}$ & $\mathbf{1 9 0}(\mathbf{7 0}-\mathbf{6 7 0})$ & $\mathbf{1 6}$ & $\mathbf{9 1 8}(\mathbf{4 5 1}-\mathbf{1 7 9 0})$ \\
\hline
\end{tabular}

Data in parenthesis show the range of values. Ring stage parasites were exposed to drug for $48 \mathrm{~h}$ in this assay. Two lab strains FC27 (CQ sensitive) and K1 (CQ resistant) were assayed as comparators using the same method. 
Table S5A. Comparison of in vivo P. falciparum efficacy with standard antimalarials

\begin{tabular}{|l|c|c|c|}
\hline Compound & $\mathrm{ED}_{90}(\mathrm{mg} / \mathrm{kg})$ & $\begin{array}{c}\text { Blood } \mathrm{AUC}_{\mathrm{ED} 90} \\
(\mu \mathrm{g} . \mathrm{hr} / \mathrm{mL}) *\end{array}$ & $\begin{array}{c}\mathrm{Blood}_{\mathrm{av}} \\
(\mu \mathrm{g} / \mathrm{mL})\end{array}$ \\
\hline DSM421 QD & 2.6 & 12.9 & 0.53 \\
\hline DSM265 QD & 8.1 & 16.7 & 0.69 \\
\hline DSM265 BID & 3.0 & 10.8 & 0.45 \\
\hline Pyrimethamine & 0.9 & 1.3 & 0.054 \\
\hline Chloroquine & 4.3 & 1.0 & 0.042 \\
\hline Mefloquine & 7.7 & 8.2 & 0.34 \\
\hline
\end{tabular}

$\mathrm{QD}$, once daily dosing; $\mathrm{BID}$, twice daily dosing. $* \mathrm{AUC}_{0-24 \mathrm{~h}}$, are shown except for the DSM265 BID data where the value is $\mathrm{AUC}_{0-12 \mathrm{~h}} \mathrm{x} 2$. Data for DSM265 were taken from ${ }^{2,5}$, data for chloroquine, mefloquine and pyrimethamine were taken from $^{5,23}$.

Table S5B. DSM421 SCID mouse blood PK data.

\begin{tabular}{|l|c|c|c|c|}
\hline $\begin{array}{l}\text { Dose } \\
(\mathrm{mg} / \mathrm{kg})\end{array}$ & $\begin{array}{c}\text { Blood }_{\text {max }} \\
(\mu \mathrm{g} / \mathrm{mL})\end{array}$ & $\begin{array}{c}\text { Blood }_{\text {min }} \\
(\mu \mathrm{g} / \mathrm{mL})\end{array}$ & $\begin{array}{c}\text { Blood } \mathrm{AUC}_{0-23} \\
(\mu \mathrm{g} / \mathrm{mL} . \mathrm{h})\end{array}$ & $\begin{array}{c}\text { Blood }_{\mathrm{av}} \\
(\mu \mathrm{g} / \mathrm{mL})\end{array}$ \\
\hline 0.1 & 0.045 & 0.007 & 0.58 & 0.024 \\
\hline 0.5 & 0.169 & 0.005 & 1.66 & 0.069 \\
\hline 1 & 0.302 & 0.035 & 3.97 & 0.17 \\
\hline 2.5 & 1.100 & 0.102 & 12.83 & 0.53 \\
\hline $\mathbf{5}$ & $\mathbf{2 . 4 9 0}$ & $\mathbf{0 . 3 2 7}$ & $\mathbf{3 0 . 8 4}$ & $\mathbf{1 . 2 9}$ \\
\hline 10 & 8.590 & 1.150 & 112.26 & 4.68 \\
\hline 30 & 18.90 & 3.290 & 255.15 & 10.6 \\
\hline
\end{tabular}

$\mathrm{ED}_{90}$ occurred at $2.5 \mathrm{mg} / \mathrm{kg} / \mathrm{day}$ and the minimum dose needed to achieve the maximum kill rate was $5 \mathrm{mg} / \mathrm{kg}$. $\mathrm{C}_{\min }$ measured at $23 \mathrm{~h}$ post-dose. 
Table S6. Comparison of physicochemical properties between DSM421 and DSM265

\begin{tabular}{|c|c|c|}
\hline Physicochemical Properties & DSM421 & DSM265 \\
\hline MW & 358.27 & 415.33 \\
\hline $\operatorname{PSA}\left(\AA^{2}\right)$ & 68.0 & 55.1 \\
\hline H-bond donors/acceptors & $1 / 6$ & $1 / 4$ \\
\hline Freely rotatable bonds (FRB) & 3 & 4 \\
\hline $\mathrm{pKa}(\mathrm{calc})^{\mathrm{a}}$ & 1.7 & $<1$ \\
\hline $\log \mathrm{D}_{\mathrm{pH} 7.4}$ (shake flask) & 2.36 & 4.0 \\
\hline Solubility $(\mu \mathrm{g} / \mathrm{mL}) \mathrm{pH} 7.4$ buffer & 82 & 2.0 \\
\hline $0.1 \mathrm{~N} \mathrm{HCl} \mathrm{pH} 1.0$ & 160 & 25 \\
\hline FaSSGF pH 1.6 & 116 & 6.8 \\
\hline FaSSIF (V2) pH 6.5 & 93 & 5.1 \\
\hline FeSSIF (V2) pH 5.8 & 119 & 27.6 \\
\hline Chemical stability & $\begin{array}{l}\text { No degradation at } 4 \text { weeks at } \\
40^{\circ} \mathrm{C} \text {; longer studies not yet run }\end{array}$ & Stable \\
\hline Caco-2 Permeability $(\mathrm{cm} / \mathrm{sec})$ & $\begin{array}{c}\text { High } \\
\left(\mathrm{P}_{\mathrm{app}}=33 \times 10^{-6}\right) \\
\end{array}$ & $\begin{array}{c}\text { High } \\
\left(\mathrm{P}_{\text {app }}=59 \times 10^{-6}\right)\end{array}$ \\
\hline
\end{tabular}

${ }^{a}$ measured values could not be determined. Data for DSM265 were taken from ${ }^{5}$

Table S7. Permeability of DSM421 across confluent and differentiated Caco-2 cell monolayers.

\begin{tabular}{|l|l|l|l|l|}
\hline \multicolumn{2}{|l|}{ Mass Balance (\%) } & \multicolumn{2}{|l|}{$\mathbf{P}_{\text {app }}\left(\mathbf{x 1 0}^{\mathbf{6}} \mathbf{c m} / \mathbf{s e c}\right)$} & \multirow{2}{*}{ Efflux Ratio } \\
\hline A-B & B-A & A-B & B-A & \\
\hline $70 \pm 4$ & $98^{\mathrm{a}}$ & $33.2 \pm 2.5$ & $46.2^{\mathrm{a}}$ & 1.4 \\
\hline
\end{tabular}

${ }^{\text {a }}$ only $\mathrm{n}=2$ measurements available

Table S8. In vitro metabolism of DSM421 in hepatic microsomes and cryopreserved hepatocytes.

\begin{tabular}{|l|c|c|c|c|}
\hline Microsomes & Human & Dog & Rat & Mouse \\
\hline In vitro $\mathrm{CL}_{\text {int }}(\mu \mathrm{L} / \mathrm{min} / \mathrm{mg}$ protein $)$ & $2.2^{\mathrm{a}}$ & $<7$ & $<7$ & $<7$ \\
\hline Fu microsomes & 0.77 & $0.77^{\mathrm{b}}$ & $0.77^{\mathrm{b}}$ & $0.77^{\mathrm{b}}$ \\
\hline Fu blood & 0.027 & 0.14 & 0.092 & 0.080 \\
\hline Predicted unbound in vivo $\mathrm{CL}_{\text {int }}(\mathrm{mL} / \mathrm{min} / \mathrm{kg})$ & 2.3 & $<17$ & $<16$ & $<24$ \\
\hline Predicted plasma CL $(\mathrm{mL} / \mathrm{min} / \mathrm{kg})$ & 0.045 & $<1.8$ & $<1.3$ & $<1.7$ \\
\hline Predicted $\mathrm{E}_{\mathrm{H}}$ & 0.003 & $<0.07$ & $<0.02$ & $<0.01$ \\
\hline
\end{tabular}

${ }^{\mathrm{a}}$ estimate only, minimal degradation even with longer incubation time

${ }^{\mathrm{b}}$ based on data in human liver microsomes

\begin{tabular}{|l|c|c|c|c|}
\hline Hepatocytes & Human & Dog & Rat & Mouse \\
\hline In vitro $\mathrm{CL}_{\text {int }}\left(\mu \mathrm{L} / \mathrm{min} / 10^{6}\right.$ cells) & $<3$ & $<2$ & $<4$ & $<2$ \\
\hline Fu hepatocytes $(\mathrm{calc})^{\mathrm{a}}$ & 0.71 & 0.71 & 0.71 & 0.71 \\
\hline Fu blood & 0.027 & 0.14 & 0.092 & 0.080 \\
\hline Predicted unbound in vivo $\mathrm{CL}_{\text {int }}(\mathrm{mL} / \mathrm{min} / \mathrm{kg})$ & $<11$ & $<17$ & $<26$ & $<20$ \\
\hline Predicted plasma CL $(\mathrm{mL} / \mathrm{min} / \mathrm{kg})$ & $<0.2$ & $<2$ & $<2$ & $<1.4$ \\
\hline Predicted $\mathrm{E}_{\mathrm{H}}$ & $<0.01$ & $<0.07$ & $<0.04$ & $<0.01$ \\
\hline
\end{tabular}

${ }^{\mathrm{a}}$ calculated as per ${ }^{1}$ 
Table S9. Plasma and media protein binding and blood to plasma partitioning ratios for DSM421.

\begin{tabular}{|l|l|l|l|l|l|l|l|l|l|l|}
\hline & Human & Dog & Rat & Mouse & $\begin{array}{l}\text { Mini } \\
\text { Pig }\end{array}$ & $\begin{array}{l}\text { SCID } \\
\text { Mouse* }\end{array}$ & $\begin{array}{l}\text { Albumax } \\
\text { media }\end{array}$ & $\begin{array}{l}10 \% \text { FCS } \\
\text { in DMEM }\end{array}$ & $\begin{array}{l}10 \% \text { human } \\
\text { serum in } \\
\text { RPMI }\end{array}$ & $\begin{array}{l}\text { HLM } \\
\text { \% Bound }\end{array}$ \\
\hline 98.1 & 88.8 & 91.7 & 92.8 & 98.2 & 97 & 50 & 37 & 85.4 & 23 \\
\hline B:P & 0.70 & 0.80 & 0.88 & 1.02 & ND & 0.6 & --- & --- & & -- \\
\hline
\end{tabular}

*estimated as described in supplemental methods

Table S10. Specific CYP-mediated metabolic pathways, conditions and reference inhibitors for reversible CYP inhibition studies

\begin{tabular}{|c|c|c|c|c}
\hline CYP Isoform & $\begin{array}{c}\text { Microsomal } \\
\text { protein }(\mathbf{m g} / \mathbf{m L})\end{array}$ & $\begin{array}{c}\text { Substrate }(\boldsymbol{\mu M}) / \\
\text { Incubation Time }(\mathbf{m i n})\end{array}$ & Metabolic pathway & Control inhibitor \\
\hline CYP1A2 & 0.4 & $40 / 30$ & phenacetin O-deethylation & furafylline \\
\hline CYP2B6 & 0.4 & $80 / 20$ & bupropion hydroxylation & ticlopidine \\
\hline CYP2C8 & 0.4 & $2 / 8$ & $\begin{array}{c}\text { amodiaquine } N- \\
\text { deethylation }\end{array}$ & quercetin \\
\hline CYP2C9 & 0.4 & $140 / 20$ & $\begin{array}{c}\text { tolbutamide } \\
\text { methylhydroxylation }\end{array}$ & sulfaphenazole \\
\hline CYP2C19 & 1.0 & $30 / 40$ & $\begin{array}{c}(S) \text {-mephenytoin } 4 \text { '- } \\
\text { hydroxylation }\end{array}$ & ticlopidine \\
\hline CYP2D6 & 0.4 & $3 / 10$ & $\begin{array}{c}\text { dextromethorphan } O- \\
\text { demethylation }\end{array}$ & quinidine \\
\hline CYP3A4/5 & 0.4 & $50 / 5$ & $\begin{array}{c}\text { testosterone } 6 \beta- \\
\text { hydroxylation }\end{array}$ & ketoconazole \\
\hline
\end{tabular}

Table S11. Reversible inhibition of CYP isoforms by DSM421.

\begin{tabular}{|c|c|}
\hline CYP isoform & IC $_{\mathbf{5 0}}(\boldsymbol{\mu} \mathbf{M})$ \\
\hline 1A2 & $>20$ (n.m.i.) \\
\hline 2B6 & $>20$ (n.m.i.) \\
\hline 2C 8 & $>20$ (n.m.i.) \\
\hline 2C9 920 (22\% inhibition) \\
\hline $2 \mathrm{C} 19$ & $>20$ (n.m.i.) \\
\hline 2D6 & $>20(45 \%$ inhibition) \\
\hline 3A4/5 & $>20$ (n.m.i.) \\
\hline
\end{tabular}

n.m.i. $=$ no measurable inhibition 
Table S12. Specific CYP-mediated metabolic pathways, conditions and reference inhibitors used for time dependent CYP inhibition studies

\begin{tabular}{|c|c|c|c|c|}
\hline $\begin{array}{c}\text { CYP } \\
\text { Isoform }\end{array}$ & $\begin{array}{c}\text { Preincubation } \\
\text { Substrate }(\mu M) / \text { Post- } \\
\text { Dilution Incubation } \\
\text { Time (min) }\end{array}$ & Metabolic Pathway & $\begin{array}{l}\text { Control Mechanism- } \\
\text { Based Inhibitor }\end{array}$ & $\begin{array}{l}\text { Control } \\
\text { Reversible } \\
\text { Inhibitor }\end{array}$ \\
\hline $1 \mathrm{~A} 2$ & $400 / 30$ & $\begin{array}{c}\text { phenacetin } \mathrm{O}- \\
\text { deethylation }\end{array}$ & furafylline & ketoconazole \\
\hline $2 \mathrm{C} 9$ & $2100 / 30$ & $\begin{array}{c}\text { tolbutamide } \\
\text { methylhydroxylation }\end{array}$ & tienilic acid & sulfaphenazole \\
\hline $2 \mathrm{C} 19$ & $200 / 40$ & $\begin{array}{c}(S) \text {-mephenytoin 4'- } \\
\text { hydroxylation }\end{array}$ & (S)-fluoxetine & ketoconazole \\
\hline 2D6 & $15 / 15$ & $\begin{array}{c}\text { dextromethorphan } O- \\
\text { demethylation }\end{array}$ & paroxetine & quinidine \\
\hline \multirow{2}{*}{$3 \mathrm{~A} 4 / 5$} & $7.5 / 10$ & $\begin{array}{l}\text { midazolam 1'- } \\
\text { hydroxylation }\end{array}$ & verapamil & ketoconazole \\
\hline & $120 / 10$ & $\begin{array}{c}\text { testosterone } 6 \beta- \\
\text { hydroxylation }\end{array}$ & verapamil & ketoconazole \\
\hline
\end{tabular}

Table S13. Time-dependent inhibition data for DSM421 against 5 major CYP isoforms.

\begin{tabular}{|c|c|c|}
\hline \multirow{2}{*}{$\begin{array}{c}\text { CYP Isoform } \\
\text { (Metabolic pathway) }\end{array}$} & \multicolumn{2}{|c|}{ IC50 $(\boldsymbol{\mu M}) /$ Preincubation condition } \\
\cline { 2 - 3 } & -NADPH & +NADPH \\
\hline 1A2 & $>20$ & $>20$ \\
\hline 2C9 & $>20$ & $>20$ \\
\hline 2C19 & $>20$ & $>20$ \\
\hline 2D6 & $>20$ & $>20$ \\
\hline 3A4/5 & $>20$ & $>20$ \\
\hline (midazolam-1'- hydroxylation) & $>20$ & \\
\hline 3A4/5 & & \\
\hline
\end{tabular}


Table S14. DSM421 dosing conditions for preclinical pharmacokinetic studies.

\begin{tabular}{|c|c|c|c|}
\hline $\begin{array}{l}\text { Dosing } \\
\text { conditions }\end{array}$ & Mice & Rats & Dogs \\
\hline strain & male Swiss outbred & male Sprague Dawley & male beagle \\
\hline fasted/non-fasted & non-fasted & $\begin{array}{l}\text { fasted (food reinstated at } 4 \mathrm{~h} \\
\text { post dose) }\end{array}$ & $\begin{array}{l}\text { fasted (food reinstated at } \\
4 \mathrm{~h} \text { post dose) }\end{array}$ \\
\hline PO formulation & $\begin{array}{l}\text { aqueous suspension in } 0.5 \% \\
\text { sodium carboxymethyl- } \\
\text { cellulose } / 0.5 \% \text { benzyl } \\
\text { alcohol } / 0.4 \% \text { Tween } 80 \text { in } \\
\text { water }\end{array}$ & $\begin{array}{l}\text { aqueous suspension in } 0.5 \% \\
\text { sodium carboxymethyl- } \\
\text { cellulose / } 0.5 \% \text { benzyl } \\
\text { alcohol / } 0.4 \% \text { Tween } 80 \text { in } \\
\text { water }\end{array}$ & $\begin{array}{l}10 \% \text { DMSO } / 90 \% \\
\text { PEG400 }\end{array}$ \\
\hline $\begin{array}{l}\mathrm{PO} \\
\text { administration }\end{array}$ & oral gavage & oral gavage & capsule \\
\hline IV formulation & $\begin{array}{l}\text { aqueous vehicle containing } \\
40 \% \text { propylene glycol / } \\
10 \% \text { ethanol / water with } \\
0.8 \% \text { Tween } 80\end{array}$ & $\begin{array}{l}\text { aqueous vehicle containing } \\
40 \% \text { propylene glycol / } 10 \% \\
\text { ethanol / water with } 0.4 \% \\
\text { Tween } 80\end{array}$ & $\begin{array}{l}10 \% \text { DMSO/90\% } \\
\text { PEG400 }\end{array}$ \\
\hline IV administration & bolus $(50 \mu \mathrm{L})$ into tail vein & $\begin{array}{l}10 \text { min infusion }(1 \mathrm{~mL}) \text { via } \\
\text { cannula in jugular vein }\end{array}$ & $\begin{array}{l}\text { bolus into the cephalic } \\
\text { vein }\end{array}$ \\
\hline Blood collection & $\begin{array}{l}2 \text { samples per mouse, } 2 \\
\text { mice per time point }\end{array}$ & $\begin{array}{l}\text { serial sampling via cannula } \\
\text { in carotid artery }\end{array}$ & $\begin{array}{l}\text { serial sampling via } \\
\text { cephalic vein (opposite } \\
\text { to that used for dosing }\end{array}$ \\
\hline
\end{tabular}


Table S15. Pharmacokinetic parameters for DSM421 following IV and oral administration to non-fasted mice. Data based on the average of two independent samples per time point.

\begin{tabular}{|c|c|c|c|c|}
\hline Mice & $\begin{array}{c}\mathrm{IV} \\
1.7 \mathrm{mg} / \mathrm{kg}\end{array}$ & $\begin{array}{c}\mathrm{PO} \\
4.5 \mathrm{mg} / \mathrm{kg}\end{array}$ & $\begin{array}{c}\mathrm{PO} \\
20 \mathrm{mg} / \mathrm{kg}\end{array}$ & $\begin{array}{c}\mathrm{PO} \\
41.5 \mathrm{mg} / \mathrm{kg}\end{array}$ \\
\hline Plasma CL (mL/min/kg) & 5.1 & & & \\
\hline Plasma $V_{\text {ss }}(\mathrm{L} / \mathrm{kg})$ & 0.8 & & & \\
\hline Plasma $\mathrm{AUC}_{0 \text {-inf }}(\mu \mathrm{g} . \mathrm{h} / \mathrm{mL})$ & 5.49 & 19.9 & 120 & 263 \\
\hline Apparent $\mathrm{t}_{1 / 2}(\mathrm{~h})$ & 1.9 & 2.0 & 1.9 & 2.3 \\
\hline $\mathrm{T}_{\max }(\mathrm{h})$ & & 2 & 1 & 1 \\
\hline Plasma $C_{\max }(\mu \mathrm{g} / \mathrm{mL})$ & & 3.11 & 22.5 & 33.3 \\
\hline Apparent bioavailability (\%) & & $>100$ & $>100$ & $>100$ \\
\hline
\end{tabular}

Table S16. Pharmacokinetic parameters for DSM421 following IV and oral administration to fasted rats. Data represent the average of two animals per dose group.

\begin{tabular}{|c|c|c|c|c|}
\hline Rats & $\begin{array}{c}\mathrm{IV} \\
2.0 \mathrm{mg} / \mathrm{kg}\end{array}$ & $\begin{array}{c}\text { PO } \\
4.3 \mathrm{mg} / \mathrm{kg}\end{array}$ & $\begin{array}{c}\mathrm{PO} \\
21.4 \mathrm{mg} / \mathrm{kg}\end{array}$ & $\begin{array}{c}\mathrm{PO} \\
53.7 \mathrm{mg} / \mathrm{kg}\end{array}$ \\
\hline Plasma CL (mL/min/kg) & 2.4 & & & \\
\hline Plasma $V_{\text {ss }}(\mathrm{L} / \mathrm{kg})$ & 0.7 & & & \\
\hline Plasma AUC ${ }_{0 \text {-inf }}(\mu \mathrm{g} . \mathrm{h} / \mathrm{mL})$ & 14.0 & 24.3 & 132 & 775 \\
\hline Apparent $t 1 / 2(h)$ & 5.3 & 4.3 & 4.4 & 4.2 \\
\hline $\begin{array}{l}\text { Fraction of dose excreted in } \\
\text { urine over } 48 \mathrm{~h}(\%)\end{array}$ & 0.6 & 0.4 & 0.4 & 1.4 \\
\hline $\mathrm{T}_{\max }(\mathrm{h})$ & & 1.8 & 4.5 & 7.5 \\
\hline Plasma $C_{\max }(\mu \mathrm{g} / \mathrm{mL})$ & & 3.24 & 14.7 & 35.5 \\
\hline Apparent bioavailability (\%) & & 80 & 88 & $>100$ \\
\hline
\end{tabular}

Table S17. Pharmacokinetic parameters for DSM421 following IV and oral administration to fasted dogs. Data represent the mean $\pm \mathrm{SD}$ for $\mathrm{n}=3$ (PO) or $\mathrm{n}=2$ (IV) dogs per dose group.

\begin{tabular}{|l|c|c|}
\hline Dogs & $\begin{array}{c}\text { IV } \\
1 \mathrm{mg} / \mathrm{kg}\end{array}$ & $\begin{array}{c}\text { PO } \\
1 \mathrm{mg} / \mathrm{kg}\end{array}$ \\
\hline Plasma CL $(\mathrm{mL} / \mathrm{min} / \mathrm{kg})$ & $0.48 \pm 0.05$ & \\
\hline${\text { Plasma } \mathrm{V}_{\mathrm{ss}}(\mathrm{L} / \mathrm{kg})} \mathrm{AUC}_{0 \text {-inf }}(\mu \mathrm{g} . \mathrm{h} / \mathrm{mL})$ & $34.3 \pm 3.3$ & $39.8 \pm 13.4$ \\
\hline Apparent t1/2 $(\mathrm{h})$ & 17.5 & 14.3 \\
\hline $\mathrm{T}_{\max }(\mathrm{h})$ & & 4.2 \\
\hline Plasma $\mathrm{C}_{\max }(\mu \mathrm{g} / \mathrm{mL})$ & & $1.73 \pm 0.35$ \\
\hline BA $(\%)$ & & $116 \pm 38.9$ \\
\hline
\end{tabular}


Table S18. DSM421 Summary of safety pharmacology data

\begin{tabular}{|l|l|l|}
\hline Assay & Study site & Result \\
\hline AMES & Wuxi & $\begin{array}{l}\text { Found none mutagenic in a 4 strain test } \pm \text { metabolic activation } \\
\text { under GLP conditions }\end{array}$ \\
\hline CYP Inhibition & Charman Lab & $>20 \mu \mathrm{M}$, all tested isoforms (see above) \\
\hline $\begin{array}{l}\text { Time Dependent } \\
\text { CYP Inhibition }\end{array}$ & Charman Lab & $>20 \mu \mathrm{M}$, all tested isoforms (see above) \\
\hline hERG & Essen & IC50=26.2 $\mu \mathrm{M}$; IC50/Cfree Hs $=52$ \\
\hline Ca_1.2 channel & Essen & $>33 \mu \mathrm{M}$ \\
\hline NaV1.5 channel & Essen & $>33 \mu \mathrm{M}, 27 \%$ at 33 $\mu \mathrm{M}$ \\
\hline $\begin{array}{l}\text { CEREP diversity } \\
\text { panel }\end{array}$ & Cerep & $\begin{array}{l}\text { No significant inhibition to tested concentration of } 10 \mu \mathrm{M} . \\
\text { Highest was } 40 \% \text { inhibition for A3(h), same as DSM265 }\end{array}$ \\
\hline
\end{tabular}


Table S19. Small molecule crystallographic data for DSM421

\begin{tabular}{|c|c|c|}
\hline Empirical formula & \multicolumn{2}{|l|}{ C14 H11 F5 N6 } \\
\hline Formula weight & \multicolumn{2}{|l|}{358.29} \\
\hline Temperature & \multicolumn{2}{|l|}{$100(2) \mathrm{K}$} \\
\hline Wavelength & \multicolumn{2}{|l|}{$0.71073 \AA$} \\
\hline Crystal system & \multicolumn{2}{|l|}{ Triclinic } \\
\hline Space group & \multicolumn{2}{|l|}{$\mathrm{P} \overline{1}$} \\
\hline \multirow[t]{3}{*}{ Unit cell dimensions } & $\mathrm{a}=9.7788(8) \AA$ & $\alpha=64.088(5)^{\circ}$. \\
\hline & $\mathrm{b}=13.1460(12) \AA$ & $\beta=86.954(6)^{\circ}$. \\
\hline & $\mathrm{c}=14.0081(12) \AA$ & $\gamma=72.713(5)^{\circ}$. \\
\hline Volume & $1540.4(2) \AA^{3}$ & \\
\hline $\mathrm{Z}$ & 4 & \\
\hline Density (calculated) & $1.545 \mathrm{Mg} / \mathrm{m}^{3}$ & \\
\hline Absorption coefficient & $0.141 \mathrm{~mm}^{-1}$ & \\
\hline $\mathrm{F}(000)$ & 728 & \\
\hline Crystal size & $0.30 \times 0.15 \times 0.12$ & \\
\hline Theta range for data collection & 1.62 to $25.35^{\circ}$ & \\
\hline Index ranges & $-11<=\mathrm{h}<=11,-15<$ & $<=1<=16$ \\
\hline Reflections collected & 15447 & \\
\hline Independent reflections & $5613[\mathrm{R}(\mathrm{int})=0.0$ & \\
\hline Completeness to theta $=25.00^{\circ}$ & $99.7 \%$ & \\
\hline Max. and min. transmission & 0.9833 and 0.9589 & \\
\hline Refinement method & Full-matrix least-s & \\
\hline Data / restraints / parameters & $5613 / 18 / 490$ & \\
\hline Goodness-of-fit on $\mathrm{F}^{2}$ & 1.023 & \\
\hline Final $R$ indices $[\mathrm{I}>2 \operatorname{sigma}(\mathrm{I})]$ & $\mathrm{R} 1=0.0664, \mathrm{wR} 2$ & \\
\hline $\mathrm{R}$ indices (all data) & $\mathrm{R} 1=0.1284, \mathrm{wR} 2$ & \\
\hline Extinction coefficient & $0.0075(9)$ & \\
\hline Largest diff. peak and hole & 0.382 and $-0.301 \mathrm{e}$ & \\
\hline
\end{tabular}


Fig. S1. Density maps for the DSM421:PfDHODH binding-site. 2mFo-DFc density map as calculated in PHENIX ${ }^{24}$ for the DSM421:PfDHODH binding-site. $2 \mathrm{mFo}-\mathrm{DFc}$ density map (blue contoured) at the $1 \sigma$ level, $\mathrm{mF}_{\mathrm{o}}-\mathrm{DF}_{\mathrm{c}}$ difference map density (red is negative and green is positive density) at the $3 \sigma$ level prior to refinement or inclusion of inhibitor into the model. DSM421 is shown in pink and protein residues and FMN are shown in yellow.

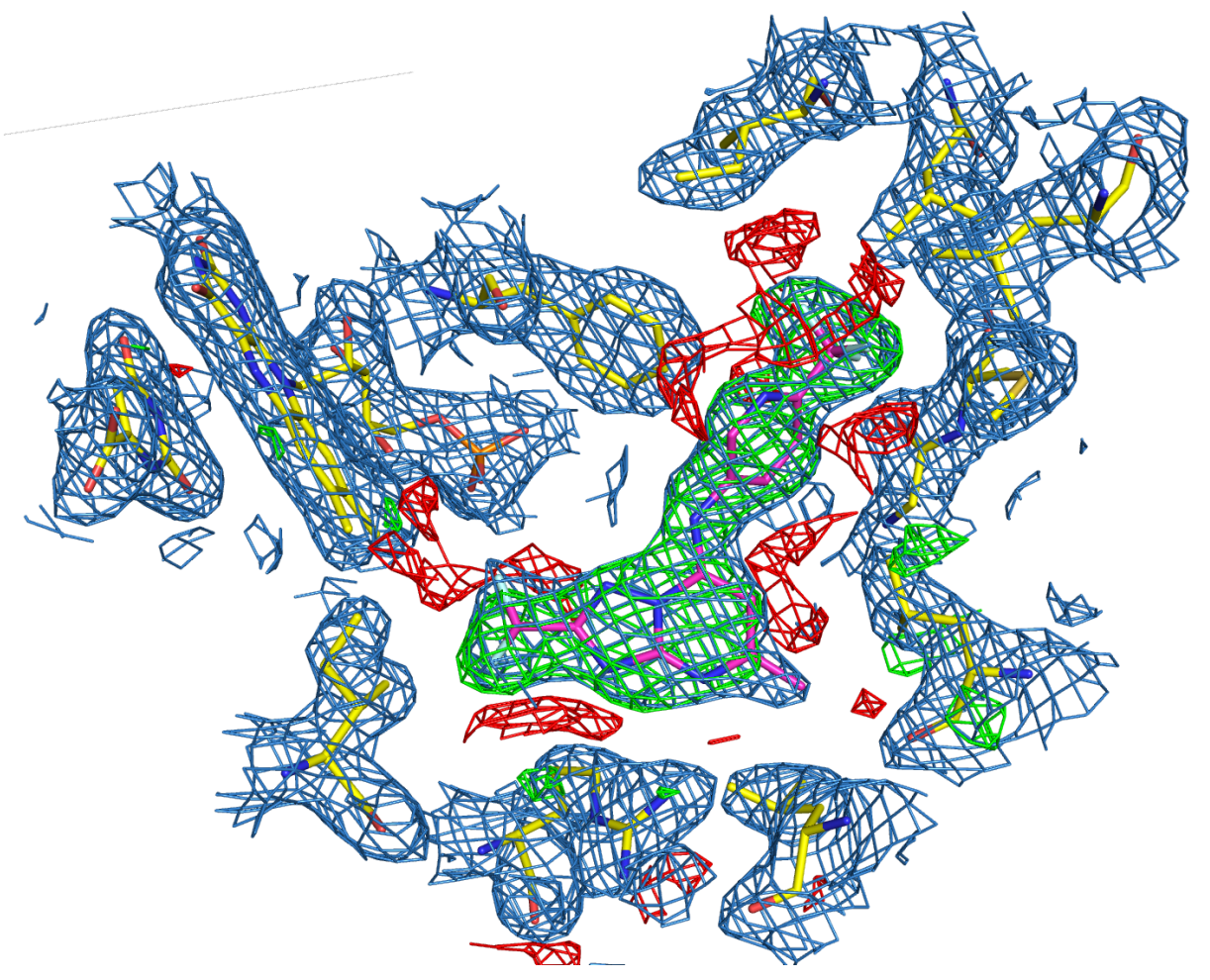


Fig. S2. Stereo view of the superimposed DSM421 and DSM265 binding sites within the $4 \AA$ shell. Superposition of the DSM265 (PDB 4RX0)(turquoise) and DSM421(purple with tan ligands) bound $P f \mathrm{DHODH}$ structures. The figure shows a stereo image of the $4 \AA$ shell around the ligands.
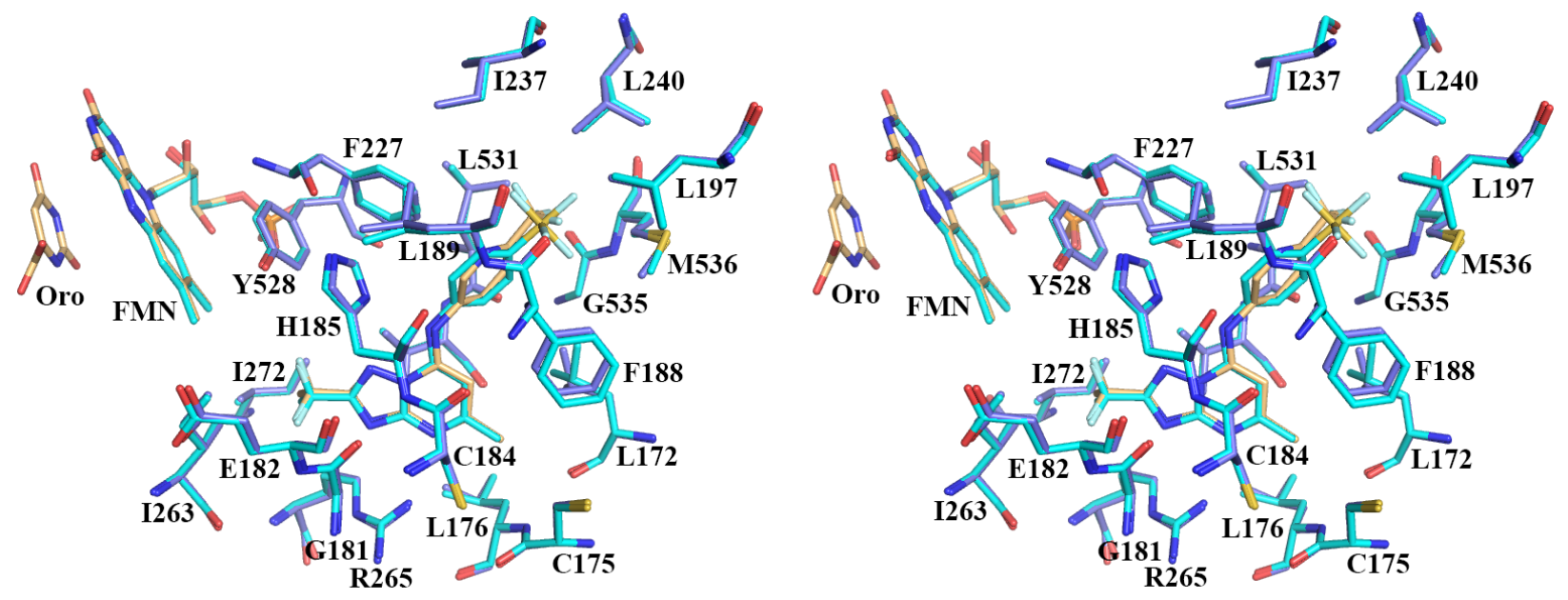
Fig. S3. ORTEP diagram of the DSM421 structure. Thermal ellipsoids at the $50 \%$ probability level. The dashed line indicates a hydrogen bond. Nitrogen N8 hydrogen-bonds to a symmetry-related molecule in a similar fashion. Disorder in C27-C28-F9-F10 omitted for clarity.

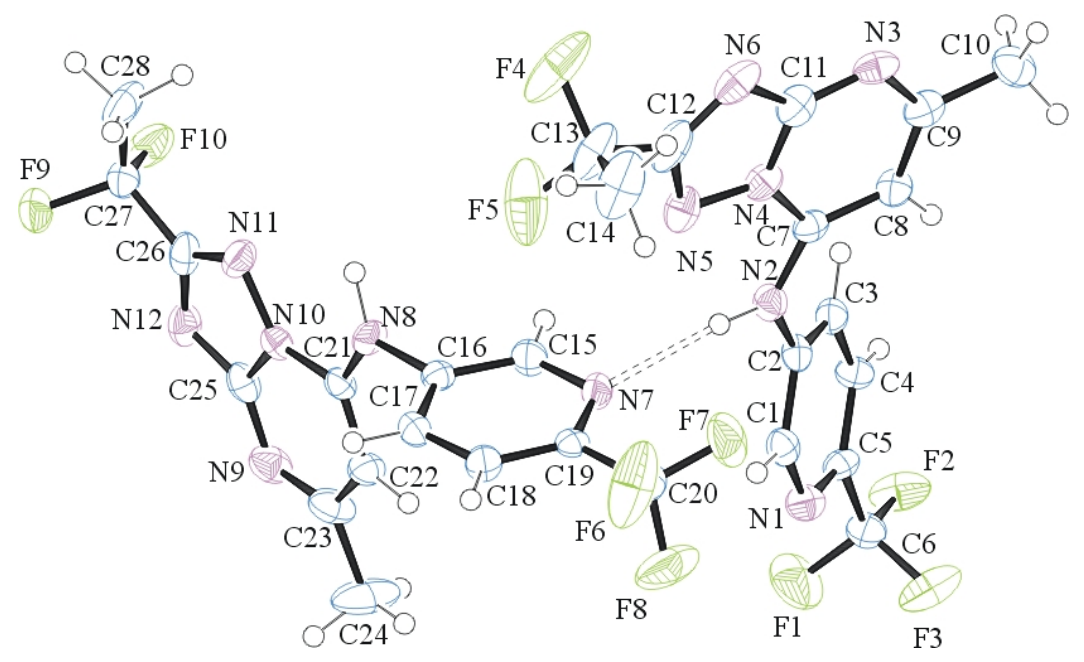




\section{Supplemental References}

[1] Ring, B. J., Chien, J. Y., Adkison, K. K., Jones, H. M., Rowland, M., Jones, R. D., Yates, J. W., Ku, M. S., Gibson, C. R., He, H., Vuppugalla, R., Marathe, P., Fischer, V., Dutta, S., Sinha, V. K., Bjornsson, T., Lave, T., and Poulin, P. (2011) PhRMA CPCDC initiative on predictive models of human pharmacokinetics, part 3: Comparative assessement of prediction methods of human clearance, J Pharm Sci 100, 4090-4110.

[2] Coteron, J. M., Marco, M., Esquivias, J., Deng, X., White, K. L., White, J., Koltun, M., El Mazouni, F., Kokkonda, S., Katneni, K., Bhamidipati, R., Shackleford, D. M., Angulo-Barturen, I., Ferrer, S. B., Jimenez-Diaz, M. B., Gamo, F. J., Goldsmith, E. J., Charman, W. N., Bathurst, I., Floyd, D., Matthews, D., Burrows, J. N., Rathod, P. K., Charman, S. A., and Phillips, M. A. (2011) Structure-guided lead optimization of triazolopyrimidine-ring substituents identifies potent Plasmodium falciparum dihydroorotate dehydrogenase inhibitors with clinical candidate potential, J Med Chem 54, 5540-5561.

[3] Rodgers, T., Leahy, D., and Rowland, M. (2005) Physiologically based pharmacokinetic modeling 1: predicting the tissue distribution of moderate-to-strong bases, J Pharm Sci 94, 1259-1276.

[4] Rodgers, T., and Rowland, M. (2006) Physiologically based pharmacokinetic modelling 2: predicting the tissue distribution of acids, very weak bases, neutrals and zwitterions, J Pharm Sci 95, 1238-1257.

[5] Phillips, M. A., Lotharius, J., Marsh, K., White, J., Dayan, A., White, K. L., Njoroge, J. W., El Mazouni, F., Lao, Y., Kokkonda, S., Tomchick, D. R., Deng, X., Laird, T., Bhatia, S. N., March, S., Ng, C. L., Fidock, D. A., Wittlin, S., Lafuente-Monasterio, M., Benito, F. J., Alonso, L. M., Martinez, M. S., Jimenez-Diaz, M. B., Bazaga, S. F., Angulo-Barturen, I., Haselden, J. N., Louttit, J., Cui, Y., Sridhar, A., Zeeman, A. M., Kocken, C., Sauerwein, R., Dechering, K., Avery, V. M., Duffy, S., Delves, M., Sinden, R., Ruecker, A., Wickham, K. S., Rochford, R., Gahagen, J., lyer, L., Riccio, E., Mirsalis, J., Bathhurst, I., Rueckle, T., Ding, X., Campo, B., Leroy, D., Rogers, M. J., Rathod, P. K., Burrows, J. N., and Charman, S. A. (2015) A long-duration dihydroorotate dehydrogenase inhibitor (DSM265) for prevention and treatment of malaria, Sci Transl Med 7, 296ra111.

[6] Toutain, P. L., and Bousquet-Melou, A. (2002) Free drug fraction vs free drug concentration: a matter of frequent confusion, J Vet Pharmacol Ther 25, 460-463.

[7] Hinderling, P. H. (1997) Red blood cells: a neglected compartment in pharmacokinetics and pharmacodynamics, Pharmacol Rev 49, 279-295.

[8] Bruker. (2007) APEX2 (Version 2.1-4), SAINT (version 7.34A), SADABS (version 2007/4), BrukerAXS Inc, Madison, Wisconsin, USA.

[9] Altomare, A., Burla, C., Camalli, M., Cascarano, L., Giacovazzo, C., Guagliardi, A., Moliterni, A., Polidori, G., and Spagna, R. (1999) SIR97: a new tool for crystal structure determination and refinement, J. Appl. Cryst. 32, 115-119.

[10] Altomare, A., Cascarano, G., Giacovazzo, C., and Guagliardi, A. (1983) Completion and refinement of crystal structures with SIR 92., J Appl Crystallogr 26, 343-350.

[11] Sheldrick, G. (1997) SHELXL97, Program for the Refinement of Crystal Structures. , University of Gottingen, Germany.

[12] Mackay, S., Edwards, C., Henderson, A., Gilmore, C., Stewart, N., Shankland, K., and Donald, A. (1997) MaXus: a computer program for the solution and refinement of crystal structures from diffraction data. , University of Glasgow, Scotland.

[13] Waasmaier, D., and Kirfel, A. (1995) New analytical scattering-factor functions for free atoms and ions., Acta Crystallogr A 51, 416-431.

[14] Evans, P. R. (2011) An introduction to data reduction: space-group determination, scaling and intensity statistics, Acta Crystallogr D Biol Crystallogr 67, 282-292.

[15] Chen, V. B., Arendall, W. B., 3rd, Headd, J. J., Keedy, D. A., Immormino, R. M., Kapral, G. J., Murray, L. W., Richardson, J. S., and Richardson, D. C. (2010) MolProbity: all-atom structure validation for macromolecular crystallography, Acta Crystallogr D Biol Crystallogr 66, 12-21.

[16] Deng, X., Kokkonda, S., El Mazouni, F., White, J., Burrows, J. N., Kaminsky, W., Charman, S. A., Matthews, D., Rathod, P. K., and Phillips, M. A. (2014) Fluorine modulates species selectivity in 
the triazolopyrimidine class of Plasmodium falciparum dihydroorotate dehydrogenase inhibitors, J Med Chem 57, 5381-5394.

[17] Vennerstrom, J. L., Arbe-Barnes, S., Brun, R., Charman, S. A., Chiu, F. C., Chollet, J., Dong, Y., Dorn, A., Hunziker, D., Matile, H., Mclntosh, K., Padmanilayam, M., Santo Tomas, J., Scheurer, C., Scorneaux, B., Tang, Y., Urwyler, H., Wittlin, S., and Charman, W. N. (2004) Identification of an antimalarial synthetic trioxolane drug development candidate, Nature 430, 900-904.

[18] Ding, X. C., Ubben, D., and Wells, T. N. (2012) A framework for assessing the risk of resistance for anti-malarials in development, Malar J 11, 292.

[19] Stickles, A. M., de Almeida, M. J., Morrisey, J. M., Sheridan, K. A., Forquer, I. P., Nilsen, A., Winter, R. W., Burrows, J. N., Fidock, D. A., Vaidya, A. B., and Riscoe, M. K. (2015) Subtle changes in endochin-like quinolone structure alter the site of inhibition within the cytochrome bc1 complex of Plasmodium falciparum, Antimicrob Agents Chemother 59, 1977-1982.

[20] Rottmann, M., McNamara, C., Yeung, B. K., Lee, M. C., Zou, B., Russell, B., Seitz, P., Plouffe, D. M., Dharia, N. V., Tan, J., Cohen, S. B., Spencer, K. R., Gonzalez-Paez, G. E., Lakshminarayana, S. B., Goh, A., Suwanarusk, R., Jegla, T., Schmitt, E. K., Beck, H. P., Brun, R., Nosten, F., Renia, L., Dartois, V., Keller, T. H., Fidock, D. A., Winzeler, E. A., and Diagana, T. T. (2010) Spiroindolones, a potent compound class for the treatment of malaria, Science 329, $1175-1180$.

[21] Jimenez-Diaz, M. B., Ebert, D., Salinas, Y., Pradhan, A., Lehane, A. M., Myrand-Lapierre, M. E., O'Loughlin, K. G., Shackleford, D. M., Justino de Almeida, M., Carrillo, A. K., Clark, J. A., Dennis, A. S., Diep, J., Deng, X., Duffy, S., Endsley, A. N., Fedewa, G., Guiguemde, W. A., Gomez, M. G., Holbrook, G., Horst, J., Kim, C. C., Liu, J., Lee, M. C., Matheny, A., Martinez, M. S., Miller, G., Rodriguez-Alejandre, A., Sanz, L., Sigal, M., Spillman, N. J., Stein, P. D., Wang, Z., Zhu, F., Waterson, D., Knapp, S., Shelat, A., Avery, V. M., Fidock, D. A., Gamo, F. J., Charman, S. A., Mirsalis, J. C., Ma, H., Ferrer, S., Kirk, K., Angulo-Barturen, I., Kyle, D. E., DeRisi, J. L., Floyd, D. M., and Guy, R. K. (2014) (+)-SJ733, a clinical candidate for malaria that acts through ATP4 to induce rapid host-mediated clearance of Plasmodium, Proc Natl Acad Sci U S A 111, E5455-5462.

[22] Meister, S., Plouffe, D. M., Kuhen, K. L., Bonamy, G. M., Wu, T., Barnes, S. W., Bopp, S. E., Borboa, R., Bright, A. T., Che, J., Cohen, S., Dharia, N. V., Gagaring, K., Gettayacamin, M., Gordon, P., Groessl, T., Kato, N., Lee, M. C., McNamara, C. W., Fidock, D. A., Nagle, A., Nam, T. G., Richmond, W., Roland, J., Rottmann, M., Zhou, B., Froissard, P., Glynne, R. J., Mazier, D., Sattabongkot, J., Schultz, P. G., Tuntland, T., Walker, J. R., Zhou, Y., Chatterjee, A., Diagana, T. T., and Winzeler, E. A. (2011) Imaging of Plasmodium liver stages to drive nextgeneration antimalarial drug discovery, Science 334, 1372-1377.

[23] Jimenez-Diaz, M. B., Mulet, T., Viera, S., Gomez, V., Garuti, H., Ibanez, J., Alvarez-Doval, A., Shultz, L. D., Martinez, A., Gargallo-Viola, D., and Angulo-Barturen, I. (2009) Improved murine model of malaria using Plasmodium falciparum competent strains and non-myelodepleted NODscid IL2Rgammanull mice engrafted with human erythrocytes, Antimicrob Agents Chemother 53, 4533-4536.

[24] Afonine, P. V., Grosse-Kunstleve, R. W., Echols, N., Headd, J. J., Moriarty, N. W., Mustyakimov, M., Terwilliger, T. C., Urzhumtsev, A., Zwart, P. H., and Adams, P. D. (2012) Towards automated crystallographic structure refinement with phenix.refine, Acta Crystallogr D Biol Crystallogr 68, 352-367. 